\title{
BRCA2 functions: from DNA repair to replication fork stabilization
}

\author{
Amélie Fradet-Turcotte1, Justine Sitz', Damien Grapton² and Alexandre Orthwein²,3 \\ 'Laval University Cancer Research Center, CHU de Québec Research Center - Université Laval, Hôtel-Dieu de \\ Québec, Oncology Axis, Quebec City, Canada \\ 2Lady Davis Institute for Medical Research, Segal Cancer Centre, Jewish General Hospital, Montreal, Canada \\ ${ }^{3}$ Department of Oncology, McGill University, Montreal, Canada
}

Correspondence should be addressed to A Orthwein or A Fradet-Turcotte Email

alexandre.orthwein@mcgill.ca or Amelie.Fradet-Turcotte@ crchudequebec.ulaval.ca

\begin{abstract}
Maintaining genomic integrity is essential to preserve normal cellular physiology and to prevent the emergence of several human pathologies including cancer. The breast cancer susceptibility gene 2 ( $B R C A 2$, also known as the Fanconi anemia (FA) complementation group D1 (FANCD1)) is a potent tumor suppressor that has been extensively studied in DNA double-stranded break (DSB) repair by homologous recombination (HR). However, BRCA2 participates in numerous other processes central to maintaining genome stability, including DNA replication, telomere homeostasis and cell cycle progression. Consequently, inherited mutations in BRCA2 are associated with an increased risk of breast, ovarian and pancreatic cancers. Furthermore, bi-allelic mutations in BRCA2 are linked to FA, a rare chromosome instability syndrome characterized by aplastic anemia in children as well as susceptibility to leukemia and cancer. Here, we discuss the recent developments underlying the functions of BRCA2 in the maintenance of genomic integrity. The current model places BRCA2 as a central regulator of genome stability by repairing DSBs and limiting replication stress. These findings have direct implications for the development of novel anticancer therapeutic approaches.
\end{abstract}
Key Words
- BRCA2
- homologous recombination
- replication stress
- DNA double-stranded break repair
- genomic stability
- Fanconi anemia
- DNA replication
- cancer therapy

\section{Introduction}

Our genome is continuously exposed to DNA-damaging agents such as ionizing radiation, ultraviolet light or DNA replication errors that can generate cytotoxic DNA lesions. The range of DNA lesions include single- (SSBs) and double-stranded DNA breaks (DSBs), inter- and intrastrand DNA crosslinks, base depurination and deamination as well as oxidative damage (reviewed in Goldstein \& Kastan (2015)). These lesions interfere with basic cellular processes and can result in DNA replication errors, stalled transcription complexes or missegregation of chromosomes during mitosis. Ultimately, the mutagenic potential of DNA lesions may lead to genomic rearrangements, a hallmark of cancer cells. Persistent DNA damage is also linked to several human pathologies, including neurodegenerative diseases, infertility, developmental disorders, immunodeficiency syndromes and accelerated aging.

To circumvent the threat posed by DNA-damaging agents, cells have evolved highly complex and specific DNA damage responses that detect, signal and ultimately repair these lesions throughout the cell cycle (reviewed in Helleday et al. (2014)). Although each type of DNA lesion activates a different pathway, there is a certain degree of overlap to maximize genome integrity. In that regard, BRCA2 plays an essential role in several DNA repair pathways, including DSB repair by homologous recombination (HR) and DNA crosslink repair by the FA pathway. The BRCA2 gene was identified in 1995

This paper forms part of a thematic review section on 20 Years of BRCA 1 and 2 The Guest Editors for this section were Kokichi Sugano and William Foulkes. 
(Wooster et al. 1995) and has been the subject of intensive research over the past 20 years. In this review, we aim to summarize the most recent findings on the role of BRCA2 in the maintenance of genome stability and their implications for the development of new therapeutic approaches. The first part of this review is dedicated to the critical domains of the BRCA2 protein while the subsequent sections detail the role of BRCA2 in HR and replication fork protection. We also address the importance of BRCA2 in FA-dependent DNA repair as this pathway is essential to resolve DNA crosslink during replication.

\section{BRCA2 structural and functional domains}

The human BRCA2 gene is located on the long arm of chromosome 13 (13q12.3) and is composed of 27 exons that encode for a protein of 3418 amino acids. BRCA2 has no apparent enzymatic activity despite initial conflicting evidence concerning a role in histone acetylation (Fuks et al. 1998, Siddique et al. 1998, Shin \& Verma 2003, Choi et al. 2012). Due to its large size, the structural and functional characterization of BRCA2 has been particularly challenging; however, the recent reconstruction of fulllength BRCA2, generated by electron microscopy, has revealed that it exists predominantly as a homodimer and has provided better mechanistic insights into the role of BRCA2 in DNA repair (Shahid et al. 2014). Several key structural elements have been identified in BRCA2 over the past two decades (Fig. 1): the BRC repeats, which consist of eight conserved motifs of about 35 amino acids (Bork et al. 1996, Bignell et al. 1997, Wong et al. 1997); the DNA-binding domain (DBD) composed of a long helical domain (HD) and three oligonucleotide/ oligosaccharide-binding (OB) folds (Yang et al. 2002); and finally the C-terminal TR2 domain (Sharan et al. 1997). BRCA2 is a predominantly nuclear protein and its subcellular localization is controlled by two distinct nuclear localization signals (NLSs) (Yano et al. 2000) and a masked nuclear export signal (NES) (Jeyasekharan et al. 2013). Finally, BRCA2 acts as a hub and recruits several regulatory proteins including RAD51 (Mizuta et al. 1997, Sharan et al. 1997, Chen et al. 1998b), the partner and localizer of BRCA2 (PALB2)/FANCN (Sy et al. 2009, Zhang et al. 2009a,b) and FANCD2 (Hussain et al. 2004), supporting the notion that BRCA2 is a multifunctional protein involved in several biological pathways (Fig. 2). In the following sections, we will detail the relevance of these unique regions with regard to the functions of BRCA2 in maintaining genomic stability.

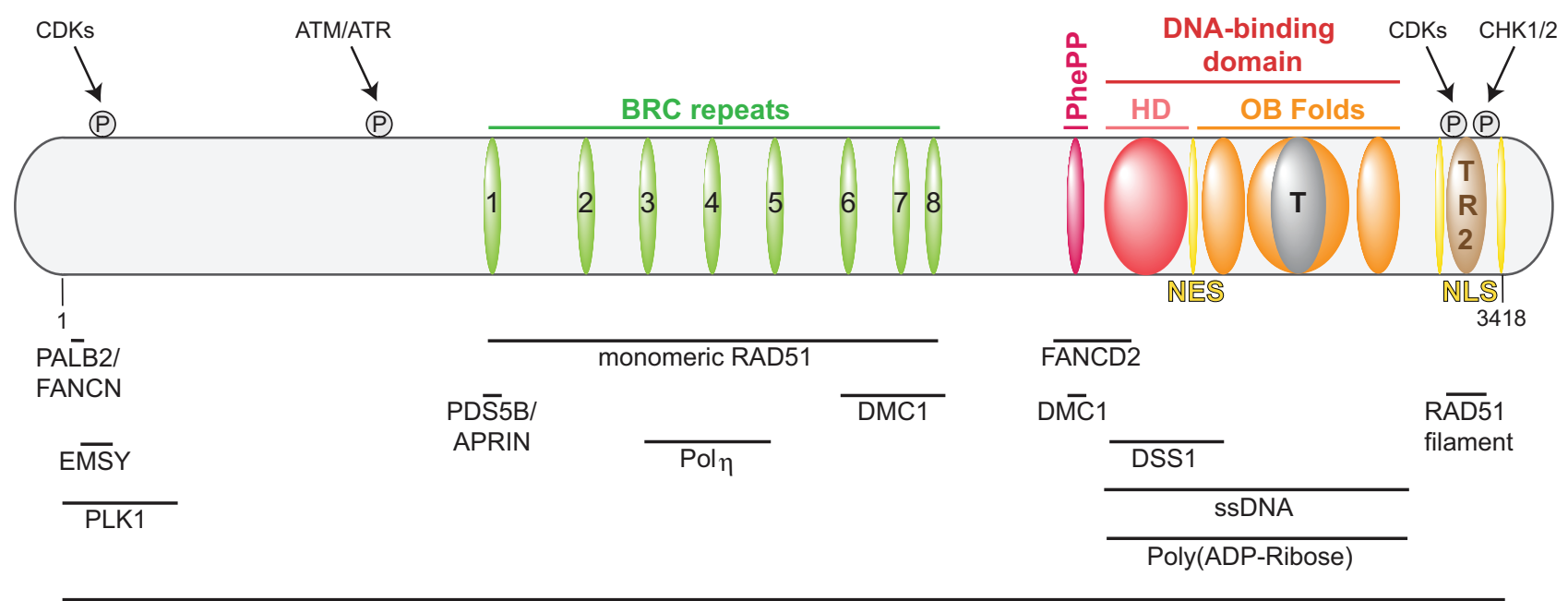

BOD1L

Figure 1

Structural domains and interaction partners of BRCA2. The N-terminal domain of BRCA2 is involved in several protein-protein interactions, including PALB2 and EMSY. BRCA2 contains eight BRC repeats located in the central portion of the protein; they are primarily involved in binding to monomeric RAD51, although they also are implicated in additional protein-protein interactions (PDS5B/APRIN and Poln). The BRCA2 DNA-binding domain (DBD) is composed of a helical domain (HD), three oligonucleotide/oligosaccharide-binding (OB) folds and a Tower domain (T). They promote BRCA2 binding to single-stranded DNA (ssDNA) and poly(ADP-Ribose). This domain also associates with DSS1. Adjacent to the DBD is a phenylalanine-proline-proline (PhePP) motif involved in the interaction with DMC1. This region is also implicated in the binding of FANCD2. The C-terminus of BRCA2 contains the TR2 domain, which interacts with RAD51 nucleofilaments. It also contains two distinct nuclear localization signals (NLSs) that are critical for BRCA2 nuclear localization. BRCA2 is posttranslationally modified by several cyclin-dependent (CDK, PLK1) and DNA damage-dependent (ATM/ATR, CHK1/2) kinases. 


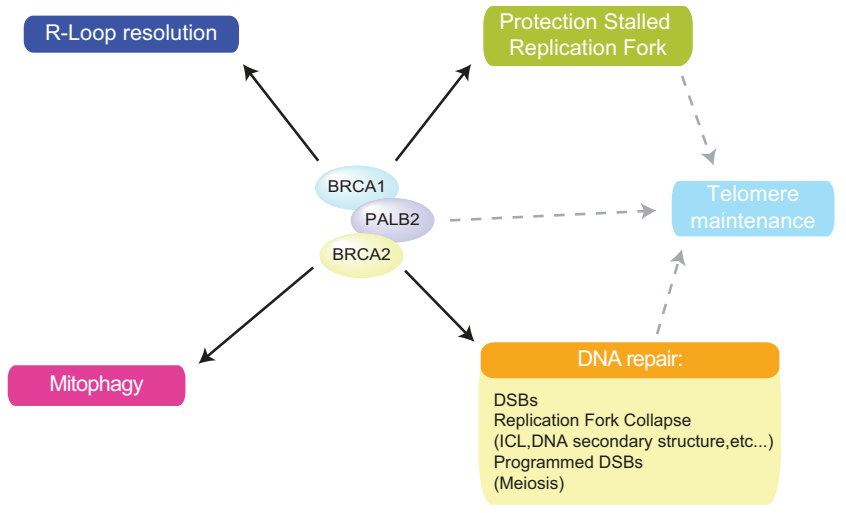

Figure 2

BRCA2 functions in the maintenance of genome stability. Bound to BRCA1 and PALB2, BRCA2 participates in multiple biological processes that are critical to maintain genome stability. First, BRCA2 is a key player in the repair of DNA lesions including DNA double-strand breaks (DSBs) and intrastrand crosslinks (ICLs). Moreover, BRCA2 has a DNA repairindependent function: it prevents nucleolytic degradation at stalled replication forks. Both of these functions are directly or indirectly involved in the maintenance of telomeres. BRCA2 is required for the processing of R-loops in collaboration with the TREX-2 complex. More recently, BRCA2 has been involved in mitophagy and the clearance of damaged mitochondria, thereby indirectly preserving genome stability.

\section{BRCA2 is a central mediator of DSB repair by $H R$}

DSBs are considered the most cytotoxic DNA lesions as one single unrepaired DSB can result in cell death (Bennett et al. 1993, Sandell \& Zakian 1993). Furthermore, DSBs can lead to major genomic rearrangements including loss of chromosome segments and chromosomal translocations. Two main and mechanistically different pathways have evolved to repair these challenging DSBs: classical nonhomologous end joining (C-NHEJ) and HR (reviewed in Betermier et al. (2014), Guirouilh-Barbat et al. (2014)). Importantly, C-NHEJ is active throughout the cell cycle, unlike HR, which is restricted to the S/G2 phases. C-NHEJ requires little to no DNA end processing and functions by rapidly ligating both DNA ends. On the other hand, HR requires the formation of extended 3' single-stranded DNA (ssDNA) tracks for homology search and strand invasion, a process called DNA end resection (Fig. 3). DNA repair pathway choice is controlled in mammalian cells by the tumor suppressors p53-binding protein 1 (53BP1) and BRCA1, which have an antagonistic relationship (Chapman et al. 2012, Escribano-Diaz et al. 2013, Tang et al. 2013). In G1 phase of the cell cycle, 53BP1 accumulates at DSBs by binding to dimethylated histone H4 (H4K20me2) (Huyen et al. 2004) and DSB-induced ubiquitylated Lys15 of histone H2A (H2AK15Ub) (Fradet-Turcotte et al. 2013). It results in an increased mobility of the chromatin surrounding the DSBs (Krawczyk et al. 2012, Lottersberger et al. 2015), although it remains unclear whether this is the case for all DNA breaks in the nucleus (Kruhlak et al. 2006, Soutoglou et al. 2007, Roukos et al. 2013). Additionally, 53BP1 promotes the recruitment of downstream effectors including the replication timing regulatory factor 1 (RIF1) (Chapman et al. 2013, Di Virgilio et al. 2013, EscribanoDiaz et al. 2013, Feng et al. 2013, Zimmermann et al. 2013), pax transactivation domain-interacting protein (PTIP) (Callen et al. 2013) and MAD2 mitotic arrest deficient-like 2 (MAD2L2) (Boersma et al. 2015, Xu et al. 2015), which are thought to limit the accessibility of BRCA1 to DSBs, thereby inhibiting DNA end resection. A recent report suggests that the association of PTIP with the nuclease Artemis (Wang et al. 2014) commits the cell into repairing DSBs by C-NHEJ. Altogether, these effector proteins promote C-NHEJ-mediated DSB repair preferentially in G1 phase of the cell cycle (reviewed in Zimmermann \& de Lange (2014)).

In $\mathrm{S} / \mathrm{G} 2$ phases, BRCA1 is recruited to DSBs, along with CtBP-interacting protein (CtIP) and the MRE11/ RAD50/NBS1 (MRN) complex, to facilitate the optimal initiation of DNA end resection (reviewed in Lamarche et al. (2010); Fig. 3); however, the contribution of BRCA1 in promoting DNA end resection is not completely understood (Nakamura et al. 2010, Reczek et al. 2013, Cruz-Garcia et al. 2014, Polato et al. 2014). Extensive resection is subsequently carried out by the DNA replication ATP-dependent helicase-like homolog (DNA2), and the Exonuclease 1 (EXO1), with the help of the Bloom syndrome helicase (BLM) (Gravel et al. 2008, Huertas et al. 2008, Mimitou \& Symington 2008, Nimonkar et al. 2008, 2011, Zhu et al. 2008, Cejka et al. 2010, Niu et al. 2010, Shim et al. 2010, Garcia et al. 2011). This two-step model of DNA end resection is primarily based on findings observed in yeast; therefore, it remains to be determined whether it is fully transposable to human cells. Exposed ssDNA stretches are rapidly coated by the Replication Protein A (RPA) complex, which protects them against nuclease cleavage and hairpin formation. In parallel to facilitating DNA end resection, BRCA1 promotes the recruitment of BRCA2 to DSBs (Chen et al. 1998a), a pivotal step in HR-mediated DSB repair. Indeed, BRCA2 stimulates the displacement of RPA and the loading of the RAD51 recombinase on ssDNA, thereby initiating homology search, strand invasion and strand exchange. Here, we discuss how BRCA2 promotes RAD51-mediated HR via its functional and structural domains. Furthermore, we review the different interactions involving BRCA2 and their relevance for HR-mediated DSB repair.

Published by Bioscientifica Ltd 

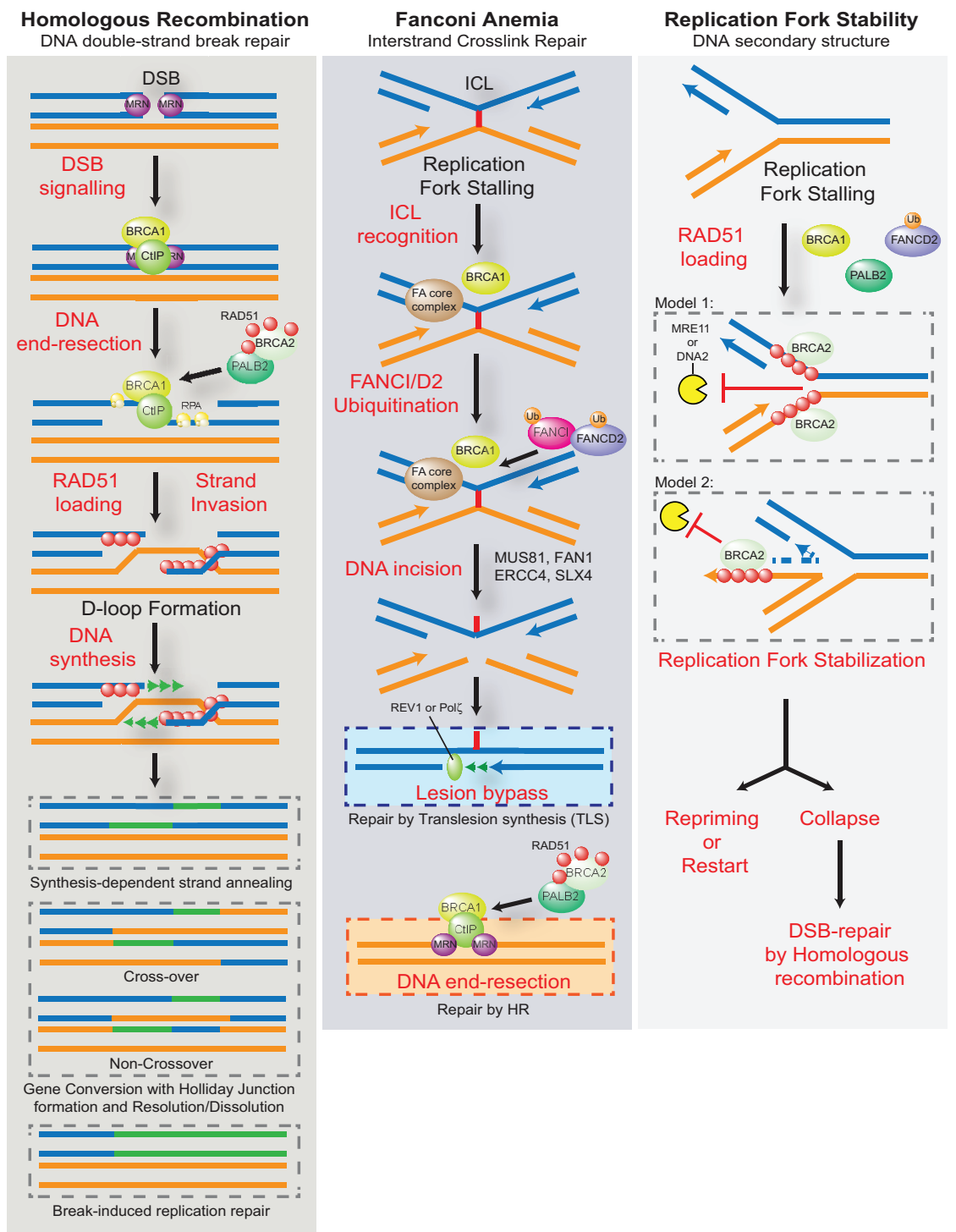

\section{Figure 3}

Role of BRCA2 during DSB repair, ICL repair and stabilization of stalled replication forks. (A) DSB is first detected by the MRE11-RAD50-NBS1 (MRN) complex, which triggers a cascade of phosphorylation and ubiquitylation events (not shown) that promote the recruitment of BRCA1 and CtIP to the break (reviewed in Dantuma \& van Attikum 2016). In S/G2 phase of the cell cycle, CtIP, along with the exonucleases Exo1 and DNA2-BLM, promotes extensive DNA end-resection, a step that commits cells to repair DSBs by homologous recombination (HR). Next, loading of RAD51 on the $3^{\prime}$-resected end by the concerted action of BRCA1/PALB2 and BRCA2 initiates homology search and the formation of a D-loop, a structure that results from the invasion of the homologous template by the RAD51-coated DNA strand. DNA synthesis and processing of the D-loop by synthesis-dependent strand annealing, gene conversion or break-induced replication repair complete this error-free DNA repair process. (B) Recognition and repair of ICLs is initiated when two replication forks converge at the lesion. The subsequent recruitment of the proteins of the Fanconi anemia (FA) core complex (FANCA, FANCB, FANCC, FANCE, FANCF, FANCG, FANCL, FANCM) along with FANCT, FAAP100, MHF1, MHF2, FAAP20 FAAP24 and BRCA1 triggers monoubiquitylation of the heterodimer FANCI/FANCD2. Once activated, the heterodimer promotes nucleolytic incision at the converged replication forks and releases the ICL from one of the strands. The latter incision, also referred as the 'unhooking', is performed by a complex composed of the nuclease scaffold (SLX4) and the endonucleases ERCC4-ERCC1, MUS81-EME1 and FAN1. Depending on their structure, the parental DNA strands will be replicated by translesion synthesis (TLS) polymerases (REV1 or POL $)$ ) or repaired by HR. (C) Following replication fork stalling, forks need to be protected from excessive resection. Although the exact molecular events that lead to their stabilization are still unclear, evidence support a role of BRCA1, BRCA2 and FANCD2 in promoting the loading of RAD51 at the fork, an event that is essential to protect the degradation of nascent strands by the nucleases MRE11 and DNA2. Whether RAD51 is loaded on ssDNA that arises on the parental strand or on the nascent strand is unknown (Models 1 and 2). The forks can be reprimed or restarted, a step that is orchestrated by the TLS polymerases. When submitted to sustained replication stress or when replication forks are unable to bypass roadblocks, forks collapse and the intervention of nucleases generates DSBs that are subsequently repaired by HR. 


\section{How does BRCA2 facilitate RAD51 loading on ssDNA?}

Upon its discovery, BRCA2 rapidly emerged as a critical component of the HR-mediated DSB repair pathway. Brca2 deletion, similar to Brca1 (Gowen et al. 1996, Hakem et al. 1996, Liu et al. 1996, Ludwig et al. 1997, Shen et al. 1998, Hohenstein et al. 2001) and Rad51 null mutants (Lim \& Hasty 1996, Tsuzuki et al. 1996), results in mouse embryonic lethality (Sharan et al. 1997, Suzuki et al. 1997). Interestingly, cells homozygous for a truncated Brca2 allele are hypersensitive to genotoxic agents (Patel et al. 1998), providing the first direct evidence of BRCA2 involvement in DNA repair. This was further corroborated when a direct role for BRCA2 in HR was demonstrated in human and mouse cell lines using GFP-based reporter assays developed to measure HR (Moynahan et al. 2001).

In the context of HR, the main function of BRCA2 is to promote the formation of RAD51 filaments on ssDNA. This in turn allows homology search and DNA strand invasion (Yuan et al. 1999), which is central to initiating DNA synthesis using the invading strand as a primer, and ultimately, HR-mediated DSB repair (Fig. 3). BRCA2 binds to monomeric RAD51 via its BRC repeats (Wong et al. 1997, Chen et al. 1998b) and the crystal structure of the BRC4 repeat in complex with RAD51 revealed that two distinct clusters of residues in the BRC repeats control RAD51 binding (Pellegrini et al. 2002, Galkin et al. 2005, Rajendra \& Venkitaraman 2010). Although the BRC repeats are highly conserved between mammalian species (Bignell et al. 1997), the individual repeats differ greatly from one another within a species, suggesting a specific role for each $B R C$ in RAD51 binding. In fact, the BRC repeats have been subdivided into two groups (BRC1-4 and BRC5-8) that, via distinct mechanisms, facilitate the loading of RAD51 onto ssDNA (Carreira \& Kowalczykowski 2011). Consistent with the role of the BRC repeats in contacting RAD51, several mutations, which affect the structure of the BRC repeats and thereby weaken RAD51 binding, have been associated with cancer predisposition (Chen et al. 1999, Li et al. 1999).

Apart from the BRC repeats, BRCA2 interacts with RAD51 through its C-terminal TR2 domain. Instead of binding to monomeric RAD51, the TR2 domain stabilizes RAD51 nucleofilaments (Davies \& Pellegrini 2007, Esashi et al. 2007). Several findings suggest that the C-terminal region of BRCA2 is critical for HR-mediated DSB repair. For instance, overexpression of the TR2 domain in wild-type human cells results in a 50\% reduction in an HR-mediated DSB repair assay (Esashi et al. 2005).
Furthermore, cells lacking the C-terminal region of Brca2 are hypersensitive to irradiation (Morimatsu et al. 1998, Donoho et al. 2003) and display reduced HR activity in GFP-based reporter assays (Moynahan et al. 2001, Tutt et al. 2001), providing direct evidence of the importance of the TR2 domain in DSB repair. This has been further corroborated in mice, where Brca2 C-terminal deletion results in increased overall tumor incidence and decreased survival (McAllister et al. 2002, Donoho et al. 2003), as well as in human, where the deletion of the C-terminal region of BRCA2 is associated with an early onset of breast and ovarian cancers (Hakansson et al. 1997). Interestingly, minimal constructs of BRCA2 encompassing the DBD and the $\mathrm{BRC}$ repeats require the $\mathrm{C}$-terminus of $\mathrm{BRCA} 2$ in order to efficiently promote HR in Brca2 mutant hamster cells (Siaud et al. 2011). Finally, CDK phosphorylation of the TR2 domain has been shown to reduce BRCA2-RAD51 binding and promotes the disassembly of RAD51 complexes at the entry of mitosis (Esashi et al. 2005, Davies \& Pellegrini 2007, Esashi et al. 2007, Ayoub et al. 2009), which could provide a way to turn off HR-mediated DSB repair in mitosis. This step may be critical to maintain genomic stability given that active DSB repair jeopardizes proper chromosome segregation in mitosis (Lee et al. 2014, Orthwein et al. 2014, Benada et al. 2015). Phosphorylation of BRCA2 C-terminus by the checkpoint kinases CHK1/CHK2 may also be relevant for BRCA2 function in HR (Fig. 2) (Bahassi et al. 2008). Altogether, these findings suggest that the regulation of the function associated with BRCA2 TR2 domain plays a central role in HR-mediated DSB repair.

\section{Importance of BRCA2 DBD during DNA repair}

A large portion of BRCA2 is dedicated to binding ssDNA: this function is mediated by a $\mathrm{HD}$ and three $\mathrm{OB}$ folds within the BRCA2 DBD (Yang et al. 2002). Several proteins involved in genome stability are characterized by the presence of one or more OB folds, including RPA (reviewed in Flynn \& Zou (2010)). Interestingly, a fusion protein of BRCA2 BRC repeats and the large RPA subunit is able to partially restore $\mathrm{HR}$ in Brca2 mutant cells, suggesting that the major function of the BRCA2 OB folds is to target BRCA2 to ssDNA and thereby promote RAD51 loading (Saeki et al. 2006). Among the BRCA2 OB folds, OB2 contains an insert of 130 amino acids named the tower domain, which improves binding to ssDNA and has been inferred to bind dsDNA (Yang et al. 2002).

Published by Bioscientifica Ltd. 
Several cancer-associated BRCA2 mutations in the DBD have been linked to defects in HR-mediated DSB repair (reviewed in Guidugli et al. (2014)), further testifying to the importance of the DBD for BRCA2 function in HR.

The BRCA2 DBD does not exclusively bind ssDNA. Indeed, the BRCA2 DBD associates with the deleted in split hand/split foot 1 (DSS1) protein (Marston et al. 1999), an interaction that is critical not only for HR-mediated DSB repair but also for BRCA2 ability to limit the accumulation of R-loops, a nucleic acid structure composed of an RNA:DNA hybrid and a displaced ssDNA (Sollier \& Cimprich 2015). Initial studies showed that DSS1 depletion results in the persistence of RAD51 foci at DSBs (Gudmundsdottir et al. 2004) and reduces BRCA2 protein levels (Li et al. 2006), but failed to define a clear role for DSS1 in HR. Subsequently, DSS1 has been found to be involved in masking a NES in BRCA2 and thereby controlling both BRCA2 and RAD51 nuclear localization (Jeyasekharan et al. 2013). New insight suggests also that DSS1 physically interacts with RPA to promote its unloading and its replacement by RAD51 on ssDNA (Zhao et al. 2015).

Besides ssDNA, the BRCA2 DBD binds to poly(ADPribose) (PAR) (Zhang et al. 2015). Interestingly, PARylation mediates the rapid recruitment of BRCA2 to DNA lesions upon laser microirradiation, which in turn promotes EXO1 mobilization and DNA end resection (Zhang et al. 2015), suggesting a BRCA1- and RAD51-independent function of BRCA2 in HR.

\section{BRCA2 acts as a scaffold for additional DSB-related factors}

A significant portion of BRCA2 is dedicated to binding RAD51. Nevertheless, BRCA2 is involved in additional protein-protein interactions. In particular, the N-terminal region of BRCA2 associates with the PALB2/FANCN (Xia et al. 2006), which physically links BRCA1 to BRCA2 in a cell cycle-dependent manner (Sy et al. 2009, Zhang et al. $2009 a, b$, Orthwein et al. 2015). This interaction is critical for the recruitment of BRCA2 to DSBs and for its role in HR (Xia et al. 2006, Oliver et al. 2009, Sy et al. 2009, Zhang et al. 2009a,b). Mutations in either BRCA2 or PALB2 that disrupt this interaction result in a drastic reduction in HR-mediated DSB repair. Importantly, these mutations are associated with breast cancer predisposition and FA syndrome (reviewed in Pauty et al. (2014) and Guidugli et al. (2014)).
Several additional interactions involving BRCA2 have been identified and studied in HR-mediated DSB repair. In particular, BRCA2 interacts with the nuclear protein EMSY through its $\mathrm{N}$-terminus. This interaction may play a role in chromatin remodeling at DSBs (Hughes-Davies et al. 2003, Cousineau \& Belmaaza 2011), but its exact relevance to DSB repair requires further investigation. The cohesinassociated protein PDS5B/APRIN is another BRCA2interacting protein that is important for HR. Unlike PALB2 and EMSY, PDS5B interacts with BRCA2 through its first BRC repeat in a cell cycle-dependent manner; abrogation of this interaction or depletion of endogenous PDS5B by RNA interference results in a significant reduction in HR (Brough et al. 2012). The importance of the PDS5BBRCA2 interaction in DSB repair was further confirmed in Drosophila, where it has recently been shown to be involved in HR-dependent meiotic recombination at the nuclear envelope (Kusch 2015). The role of BRCA2 in meiosis is not restricted to its interaction with PDS5B. Indeed, loss of Brca2 in plants (Siaud et al. 2004, Seeliger et al. 2012) and mice (Sharan et al. 2004) led to impaired meiosis, likely due to Brca2 binding with the meiosis-specific recombinase DNA meiotic recombinase 1 (DMC1) via a phenylalanine-proline-proline (PhePP) motif in BRCA2 (Dray et al. 2006, Thorslund et al. 2007, Seeliger et al. 2012). Nevertheless, disruption of the PhePP motif in mice had no impact on meiosis (Biswas et al. 2012), suggesting that additional domains in BRCA2 mediate its function during meiosis. Indeed, a recent report showed that the BRC repeats of BRCA2 directly bind to DMC1 and stimulate DMC1-mediated DNA strand exchange (Martinez et al. 2016). Altogether, BRCA2 coordinates both RAD51and DMC1-mediated recombination events, thereby promoting DSB repair in both somatic and germinal cells.

\section{BRCA2 is a guardian of genomic stability upon replication stress}

DNA replication fork stalling represents a constant threat for the maintenance of genomic integrity (Zeman \& Cimprich 2014). To circumvent replication stress, cells have evolved complex responses that prevent replication forks from collapsing and that deal with roadblocks which restrain their progression (Berti \& Vindigni 2016). Here, we discuss the role of BRCA2 in the protection and restart of stalled forks as well as in the processing of transcriptioninduced DNA:RNA hybrids (R-loops). Finally, we review the novel therapeutic approaches that have emerged from these findings.

Published by Bioscientifica Ltc. 


\section{BRCA2 protects stalled replication forks from nucleolytic degradation}

During DNA replication, progression of the replication forks can be hampered by many elements including DNA lesions (base damages, SSBs, ICLs), secondary structures (G-quadruplex and R-loops), repetitive elements and nucleotide pool depletion (Zeman \& Cimprich 2014). This process triggers an ataxia telangiectasia mutated (ATM)- and Rad3-related (ATR)-dependent signaling pathway that activates a cell cycle checkpoint and facilitates replication fork processing (reviewed in Flynn \& Zou (2011)) (Fig. 3). Depending on the nature and the persistence of the stress, stabilized forks can either restart or collapse (Berti \& Vindigni 2016). To promote restarting of forks, nascent strands need to undergo limited resection. While the exact mechanism by which resection contributes to the processing of stalled replication forks is currently unknown, both its inhibition and its overactivation are detrimental for replication fork restart (Buis et al. 2008, Hashimoto et al. 2010, Schlacher et al. 2011). Two key nucleases, the meiotic recombination 11 (MRE11) and DNA2, are thought to drive this step (Costanzo et al. 2001, Trenz et al. 2006, Hashimoto et al. 2010, Buisson et al. 2014, Thangavel et al. 2015); however, the mechanism(s) by which these nucleases recognize and process stalled forks remain unclear. Recent studies suggest that poly (ADP-ribose) polymerase 1 (PARP1) and the histone methyltransferase complex PTIP/mixedlineage leukemia protein 3 et 4 (MLL3/4) promote the recruitment of MRE11 to stalled forks (Bryant et al. 2009, Ying et al. 2012, Chaudhuri et al. 2016). On the other hand, DNA2 acts together with the Werner syndrome ATP-dependent helicase (WRN) at reversed replication forks (Thangavel et al. 2015). The current model proposes that DNA2 and MRE11 accumulate on different types of stalled forks depending on their structures and the moment at which they appear (Karanja et al. 2014, Higgs et al. 2015, Thangavel et al. 2015). Nevertheless, the recent finding that the Fanconi-associated nuclease 1 (FAN1) is also implicated in replication fork recovery (Lachaud et al. 2016, Chaudhury et al. 2014) suggests that this model is much more complex than initially anticipated.

Limited resection that occurs at stalled forks needs to be tightly regulated as uncontrolled nucleolytic degradation leads to genomic instability in Fanconi anemia (FA)- and BRCA1/2-deficient cancer cells (Schlacher et al. 2011, Schlacher et al. 2012, Ying et al. 2012, Berti \& Vindigni 2016). BRCA2 is a key player in the processing of replication forks. For instance, stalled replication forks, characterized by the formation of Y-shaped DNA intermediates on two-dimensional gel electrophoresis, disappear quickly after replication stress is induced in BRCA2-deficient cells (Lomonosov et al. 2003). Although BRCA2 has never been detected at stalled replication forks, its colocalization with PALB2, RAD51, proliferating cell nuclear antigen and RPA at replication stress-induced foci (Buisson et al. 2014) and its ability to protect the nascent DNA strand from degradation by MRE11 in DNA fiber assays (Schlacher et al. 2011, Ying et al. 2012, Buisson et al. 2014) suggest that it plays a direct role in stalled replication fork processing. The current model places RAD51 nucleofilament stabilization by BRCA2 as a key step for the protection of nascent replication tracks: nascent DNA strand protection requires that BRCA2 interacts with monomeric RAD51 through its BRC repeats and stabilizes RAD51 filaments via its TR2 domain (Schlacher et al. 2011). Consequently, cells under replication stress block the CDK-mediated phosphorylation of the TR2 domain (S3291) (Fig. 1), which is known to abolish the binding of BRCA2 to nucleofilaments (Esashi et al. 2005). This inhibition is driven by ATR signaling and the components of the core Hippo pathway, large tumor suppressor kinase 1 (LATS1) and Ras association domain family 1 isoform A (RASSF1A) (Pefani et al. 2015). Interestingly, the inability of a BRCA2 S3291A mutant to rescue the stalled fork stability in BRCA2-deficient cells suggests that a dynamic phosphorylation of this residue is required to complete replication fork recovery (Schlacher et al. 2011). BRCA2 also promotes the association of RAD51 with stressed replication forks by facilitating its phosphorylation by polo-like kinase 1 (PLK1) (Yata et al. 2014). This function relies on a direct interaction between the CDK2phosphorylated N-terminal domain of BRCA2 (T77 site) and the phospho-binding polo box domain of PLK1 (Fig. 1). Finally, stalled fork protection does not depend on the ability of BRCA2 to interact with DNA, suggesting that the main role of BRCA2 at stalled replication forks is to load and stabilize polymerized RAD51 (Schlacher et al. 2011).

\section{BRCA2 partners contribute to replication fork protection}

As mentioned previously, BRCA1 and PALB2 promote the recruitment of BRCA2 at DSBs, but recent findings suggest that they may play a similar role at stalled replication forks. Indeed, PALB2 colocalizes with BRCA2 at stalled and

Published by Bioscientifica Ltd 
collapsed replication forks in HeLa cancer cells (Buisson et al. 2014) and replication forks are destabilized in Brca1-deficient mouse ES cells upon replication stress (Schlacher et al. 2012).

Several factors, including FANCD2 and the newly identified protein biorientation of chromosomes in cell division 1 like (BOD1L), coimmunoprecipitate with BRCA2 and promote stalled fork protection through the stabilization of RAD51 filaments (Schlacher et al. 2012, Higgs et al. 2015). BOD1L actively inhibits the processing of nascent strands by DNA2, BLM and FBH1 proteins (Higgs et al. 2015), but it remains unclear how the interplay of BRCA2 and BOD1L is functionally relevant in this context. Similarly, the BRCA2-FANCD2 interaction has been observed in both two hybrids of yeast and coimmunoprecipitation experiments (Hussain et al. 2004, Wang et al. 2004, Higgs et al. 2015); however, its relevance for stalled replication fork protection has yet to be elucidated. FANCD2 affects several important biological pathways including DNA synthesis, replication fork restart and alternative end-joining repair, all of which could influence the recovery of stalled forks (Lossaint et al. 2013, Kais et al. 2016, Lachaud et al. 2016, Michl et al. 2016). As detailed in the following section, FANCD2 needs to be monoubiquitylated to promote ICL repair; however, at stalled replication forks, the role of this posttranslational modification is largely debated (Schlacher et al. 2012, Raghunandan et al. 2015). Furthermore, the involvement of FANCD2 in resolving replication stress has mainly been described in BRCA1/2-deficient tumors; thus, the cooperation of FANCD2 with BRCA2 in the protection of stalled replication fork is still debated in normal cells.

Recent findings involve additional factors in the maintenance of genomic stability upon replication stress. In particular, the nucleosome-remodeling factor chromodomain helicase DNA-binding protein 4 (CHD4) was recently shown to promote resistance to replicative stress in BRCA1/2-deficient cells (Guillemette et al. 2015, Chaudhuri et al. 2016). Thus, the latter discovery provided insight into the mechanism by which factors accumulate at stalled replication forks impact its processing. Moreover, it highlights the interesting possibility that new players in the stabilization of replication remain to be identified.

\section{Role of BRCA2 in replication forks processing}

Cells must complete the replication of their genetic material before division. To achieve this goal while maintaining genomic stability, they have evolved multiple alternative ways to deal with stalled replication forks. First, cells can counteract the presence of DNA lesions by restarting stalled forks through fork repriming or fork reversal (Berti \& Vindigni 2016). While fork repriming relies mainly on the activity of translesion synthesis (TLS) polymerases (Berti \& Vindigni 2016), recent findings support a role of RAD51 and BRCA2 in fork reversal and restart (Petermann et al. 2010, Yata et al. 2014, Raghunandan et al. 2015, Zellweger et al. 2015). This observation remains debatable as replication restart is not impacted in RAD51- and BRCA2-deficient cells using a DNA fiber assay (Schlacher et al. 2011).

When replication forks experience prolonged replication stress or when stalled forks failed to restart, they collapse and their processing by nucleases such as MUS81 lead to the generation of one-ended DSBs (Berti \& Vindigni 2016) (Fig. 3). Repair of these breaks by HR restores a proper template for DNA replication and limits genomic instability. DSBs can also arise when replication forks encounter roadblocks that are particularly hard to bypass such as the covalent linkage between the Watson and Crick strands of DNA that are formed in ICLs. These DNA lesions are induced by compounds such as platinum-based cisplatin or mitomycin C (MMC), and are particularly toxic in patients that suffer from FA.

FA is a rare autosomal recessive disease caused by the inactivation of one of the 19 FA genes and is characterized by a spectrum of clinical disorders, including congenital abnormalities, progressive bone marrow failure and predisposition to cancer development (Ceccaldi et al. 2016). BRCA2 has been classified as an FA-like gene following the discovery of a subgroup of patients suffering from FA due to a mutation in BRCA2 (Howlett et al. 2002). At the molecular level, the processing and repair of ICLs is initiated by the coordinated action of the FA core complex (composed of FANCA, FANCB, FANCC, FANCE, FANCF, FANCG, FANCL, FANCM), as well as FANCT, FAAP100, MHF1, MHF2, FAAP20, FAAP24 and BRCA1, upon the convergence of two replication forks to the lesion (reviewed in Ceccaldi et al. (2016); Fig. 3). Following the accumulation of the FA core complex to an ICL, monoubiquitylation of the FANCD2-FANCI heterodimer by the E3 ubiquitin ligase FANCL promotes its loading on chromatin. This ubiquitination event is central to the recruitment of multiple downstream effectors: the nuclease complexes that promote ICL unhooking via DNA incision, the polymerases that promote TLS and the HR proteins that promote DSB repair (Zhang \& Walter 2014). TLS polymerases enable replication by bypassing a lesion on one DNA strand while HR drives repair on the second parental strand

Published by Bioscientifica Ltd 
where a one-ended DSB has been generated by the DNA incision (Fig. 3). Interestingly, recombination-associated DNA synthesis may also contribute to DNA repair at stalled forks. In this condition, the interaction of BRCA2 and PALB2 with polymerase $\eta$ (Pol $\eta$ ) has been suggested to promote the extension of D-loop substrates following RAD51-mediated strand invasion (Buisson et al. 2014).

During these processes, BRCA2 has long been thought to promote repair by its function in HR (discussed previously). However, the importance of BRCA2 and RAD51 in the protection of stalled forks raises the possibility of their involvement in the stabilization/ processing of forks that encounter ICLs. Indeed, RAD51 localizes in the proximity of ICLs independently of FANCD2 and before the detection of DSBs (Long et al. 2011, Wang et al. 2015). Further investigation will be required to determine whether BRCA2 participates in the loading of RAD51 at ICLs before the formation of DSBs.

\section{BRCA2 safeguards the integrity of DNA against specific secondary structures}

Across the genomic landscape, the formation of secondary structures challenges DNA replication (Zeman \& Cimprich 2014). In BRCA2-depleted cells, the accumulation of R-loops as well as the inability of cells to maintain telomere integrity (telomeres are G-rich regions that can form G-quadruplexes) suggests that BRCA2 facilitates DNA replication across challenging DNA structures. Interestingly, the ability of BRCA2 to process R-loops and maintain telomeres integrity may be independent of its functions at stalled fork protection and in DNA repair (discussed below).

BRCA2 limits R-loops accumulation R-loops are highly stable structures that are formed when a nascent RNA transcript interacts with a complementary DNA sequence, a phenomenon that results in the formation of an RNA:DNA hybrid and a displaced ssDNA. In normal cells, R-loops often formed at gene promoters and terminators, and their life time is regulated by RNAse H1, which degrades RNA:DNA hybrids, and by putative helicases (Aquarius Intron-Binding Spliceosomal Factor $(\mathrm{AQR})$ and senataxin (SETX)), which specifically unwind R-loops (Sollier \& Cimprich 2015). Although these loops have an important role in the regulation of gene expression and immunoglobulin class switching (reviewed in Sollier \& Cimprich (2015)), their uncontrolled accumulation impedes the progression of replication forks and creates genomic instability. R-loop-linked genomic instability is particularly exacerbated in BRCA $1 / 2$ tumors cells as well as in cells isolated from FA patients (Kee \& D'Andrea 2012, Hatchi et al. 2015). Consistent with this observation, depletion of BRCA2, BRCA1 or the FAgenes (FANCD2, FANCA, FANCM, FANCL) lead to the accumulation of R-loop and to a concomitant increase in the number of chromosomal aberrations in these cells (Bhatia et al. 2014, Garcia-Rubio et al. 2015, Hatchi et al. 2015, Schwab et al. 2015). Nevertheless, it remains largely unclear how R-loops promote genomic instability in this context. Interestingly, R-loops do not accumulate in RAD51depleted cells, supporting a model where BRCA2 impacts R-loop formation independently of its ability to recruit and stabilize RAD51 on ssDNA (Bhatia et al. 2014). BRCA2 was proposed to limit the accumulation of R-loops by cooperating with the TREX-2 complex, which is involved in mRNP biogenesis and export (Bhatia et al. 2014). The interaction of BRCA2 with TREX-2 complex may occur via DSS1 (Fig. 1); however, further investigation will be required to validate this hypothesis. The role of BRCA2 in preventing the formation of RNA:DNA hybrids differs greatly from the role of BRCA1 in this process. Indeed, the mutational signatures of specific transcription termination sites are different in BRCA1- and BRCA2-null tumors (Hatchi et al. 2015), supporting the hypothesis that both BRCA proteins target R-loops in different regions of the genome (Hatchi et al. 2015). Moreover, BRCA1 counteracts the accumulation of R-loops by recruiting SETX to a subset of transcription termination regions from highly transcribed genes (Hatchi et al. 2015). It is still unclear how BRCA2 is involved in limiting R-loops, but as mentioned above, other components of the FA pathway contribute to their regulation. Thus, it is possible that BRCA2 collaborates with FA genes to limit the appearance of the RNA:DNA hybrids and its associated genomic instability. In these conditions, resolution of R-loops is dependent on the translocase activity of FANCM (Schwab et al. 2015).

BRCA2 protects telomere integrity Telomeres are another tedious DNA structure to replicate due to the presence of a highly repetitive G-rich sequence (TTAGGG). As the maintenance of telomeres is essential to prevent genomic instability, two mechanisms safeguard their integrity: (1) the maintenance of telomere length and (2) the formation of a protective telomeric structure, the T-loop or cap, which prevents their recognition by DNA repair signaling (Doksani \& de Lange 2014). Telomere length is maintained by the concomitant actions of the replication machinery and of a specialized reverse

Published by Bioscientifica Ltd. 
transcriptase (telomerase) (Blackburn \& Collins 2011). Alternatively, elongation is achieved by an HR-mediated process, called the alternative lengthening of telomeres (ALTs). Interestingly, HR factors such as RAD51 facilitate the formation of T-loop structures (reviewed in Doksani \& de Lange (2014)).

The idea that BRCA2 is involved in telomere maintenance originates from the observation that the conditional knock-out (cKO) of Brca2 leads to telomere shortening in mice (Badie et al. 2010, Min et al. 2012). Although BRCA2 is required to load RAD51 on telomeres (Badie et al. 2010), the exact mechanism by which it safeguards telomere integrity is still not clearly defined. The detection of telomere fusions in BRCA2 cKO cells suggests that it facilitates telomere capping potentially by modulating the formation of T-loops. Furthermore, the presence of telomere abnormalities in these cells suggests that BRCA2 is required to limit replication stress at telomeres (Badie et al. 2010, Min et al. 2012). Consistent with a role of BRCA2 in assisting the replication of G-rich sequences at telomeres, a stabilizer of G-quadruplex structures (pyrodostatin (PDS)) was shown to induce lethality in BRCA2-deficient cells (Zimmer et al. 2016). Thus, the current model proposes that BRCA2 safeguards telomeric integrity by facilitating their replication (Badie et al. 2010, Min et al. 2012, Zimmer et al. 2016). Interestingly, BRCA1 participates in the protection of stalled forks in G-quadruplex structures (Zimmer et al. 2016) but is dispensable for the maintenance of telomere length (Badie et al. 2010). Altogether, these findings suggest that the role of BRCA2 in the maintenance of telomeres is independent of BRCA1.

\section{Novel therapeutic approaches}

Multiple chemotherapeutic agents induce replication stress either by producing DNA damages that block replication fork progression (such as alkylating agents (temozolomide, MMC, etc.) and platinum compounds (cisplatin, carboplatin, etc.)) or by slowing down their progression via the depletion of nucleotide pools (such as nucleoside and base analogs (gemcitabine, 5-fluorouracil, etc.)) (Dobbelstein \& Sorensen 2015). Tumors that are deficient in BRCA1/2 genes are particularly susceptible to these replication poisons as they are neither efficient at protecting cells from replication stress nor capable of repairing DSBs by HR (detailed within this special issue by Dhillon et al. (2016)). Consequently, these tumor cells ultimately die from high levels of genomic instability.
Aside from these traditional chemotherapeutics, compounds targeting the signaling cascade that are triggered upon ssDNA damage can also induce replication stress (Dobbelstein \& Sorensen 2015). Among those, small molecules that inhibit the function of PARP1 (PARP inhibitors (PARPi)) are particularly potent at inducing cell death in BRCA1/2-deficient tumors (Bryant et al. 2005, Farmer et al. 2005). Unfortunately, tumors acquire resistance to PARPi through the restoration of HR-mediated DSB repair. For instance, relapse is observed when cells acquire mutations in genes that block DNA end resection (53BP1, MALD2L2) in $B R C A 1$-deficient cells while secondary mutations in $B R C A 2$ can rescue its functions in HR (Lord \& Ashworth 2013). Resistance of the tumors to PARPi thus raise new challenges for cancer treatment.

Interestingly, recent findings in BRCA1/2-deficient cells revealed that resistance to PARPi can occur in an HR-independent manner by acquiring mutations that rescue replication fork stability (Chaudhuri et al. 2016, Kais et al. 2016, Michl et al. 2016). Deletion of PARP1, PTIP and CHD4 as well as FANCD2 overexpression provide increased resistance to replication stress in BRCA1/2-deficient cells (Schlacher et al. 2012, Guillemette et al. 2015, Chaudhuri et al. 2016, Kais et al. 2016, Michl et al. 2016). Although the exact mechanisms by which these proteins participate in the stabilization of stalled replication forks remain elusive, these observations provide a rational to target these factors in the case of relapse/resistance to current therapies. The lethality induced by FANCD2 abrogation in BRCA2-deficient cells (Michl et al. 2016) can be exploited therapeutically to treat BRCA2-deficient tumors. Similarly, the mediator of RAP80 interactions and targeting subunit of $40 \mathrm{kDa}$ (MERIT40), a subunit of the receptor-associated protein 80 (RAP80) ubiquitin recognition complex involved in the targeting of BRCA1 to DNA damage sites, has recently been implicated in the processing of ICLs and could be an interesting target for anticancer therapy (Jiang et al. 2015). Indeed, the increased chromosomal aberrations observed in Merit40- and Brca2-deficient mouse embryonic fibroblasts highlights the relevance of targeting MERIT40 in BRCA2-deficient tumor cells.

Although cell death is not an obligate immediate consequence of replication stalling (Schlacher et al. 2011, 2012), cells that are unable to deal with replication stress accumulate high levels of chromosomal aberrations. The mechanisms by which replication poisons promote cell death in tumors undergoing high levels of replication stress are elusive. Nevertheless, excessive replication

Published by Bioscientifica Ltd. 
stress and concomitant synthetic lethality occurs in BRCA2-deficient mice as well as in human cells treated with pyridostatin (PSD), a small molecule that stabilizes G4 structures that assemble on G-rich DNA strands (Zimmer et al. 2016). Consistent with the ability of this molecule to stabilize replication roadblocks, PSD leads to replication stress in cells depleted in BRCA1 or RAD51 (Zimmer et al. 2016). Thus, PSD could provide a therapeutic alternative for treating BRCA1/2-deficient tumors. Importantly, it may provide another ways to counteract the growth of BRCA1-deficient tumors that have acquired resistance to the PARP inhibitor Olaparib through the loss of 53BP1 or $M A D 2 L 2$, as PSD efficacy is conserved in these conditions (Zimmer et al. 2016).

\section{Conclusion and future directions}

BRCA2 is a key player in the maintenance of genomic stability. In the past few years, we have witnessed major contributions delineating the role of BRCA2 in HR-mediated DSB repair. Moreover, we have come to the understanding that BRCA2 is a central factor in the protection of stalled replication forks. Aside from these functions, this multifaceted protein is involved in numerous other biological processes that impact genome stability, including chromosome segregation during mitosis and cell cycle progression (addressed in Lee 2014). Indeed, aneuploidy is a common feature of BRCA2-deficient cells and this phenomenon is linked to BRCA2 functions in the regulation of centrosome duplication (Schlacher et al. 2012, Guillemette et al. 2015, Chaudhuri et al. 2016, Kais et al. 2016, Michl et al. 2016), cytokinesis (Daniels et al. 2004, Mondal et al. 2012) and spindle assembly checkpoint during $\mathrm{M}$ phase (Choi et al. 2012). Future investigation will be vital to understand how the integration of all BRCA2 functions preserves genome integrity. In particular, in vivo phosphorylation of BRCA2 by the ATM and ATR has been detected in response to DNA damage (Matsuoka et al. 2007); however, its biological relevance has yet to be determined. Furthermore, novel functions of BRCA2 have been reported and could influence our model of its role in genome stability. Although BRCA2 functions have so far taken place in the nucleus, a recent study raises the intriguing possibility that BRCA2, along with BRCA1 and multiple proteins of the FA pathway (FANCA, FANCF, FANCL, FANCD2), facilitates mitophagy, a cytoplasmic process that targets damaged mitochondria to selective autophagy (Sumpter et al. 2016). Mitophagy is critical to maintain low level of mitochondrial reactive oxygen species (mtROS), and recent evidence suggests that the accumulation of mtROS impacts transformation and tumors progression (Chourasia et al. 2015). Therefore, understanding BRCA2 functions in the cytoplasm may shed new light on its role as a tumor suppressor. Collectively, efforts in elucidating the different roles of BRCA2 have already offered exciting opportunities to treat patients affected by BRCA2related pathologies. We believe that continued efforts in BRCA2 research will open new therapeutic options for the prevention and the treatment of breast, ovarian and pancreatic cancer.

Declaration of interest

The authors declare that there is no conflict of interest that could be perceived as prejudicing the impartiality of this review.

\section{Funding}

A O receives a Transition Grant from the Cole Foundation and is supported by the Sir Mortimer B Davis Foundation from the Jewish General Hospital and a CIHR Project grant (\#361708). A F T holds a Canadian Research Chair in Molecular Virology and Genomic Instability and is supported by a Scholarship for Next Generation of Scientist grant from the Cancer Research Society and a Discovery Grant from NSERC.

\section{Acknowledgements}

We are grateful to Stephen P Methot, Lee Zou, Giuseppina Ursini-Siegel, Chantal Autexier and Michael Witcher for critically reading the manuscript and to Andre Nussenzweig for sharing data.

\section{References}

Ayoub N, Rajendra E, Su X, Jeyasekharan AD, Mahen R \& Venkitaraman AR 2009 The carboxyl terminus of Brca2 links the disassembly of Rad51 complexes to mitotic entry. Current Biology 19 1075-1085. (doi:10.1016/j.cub.2009.05.057)

Badie S, Escandell JM, Bouwman P, Carlos AR, Thanasoula M, Gallardo MM, Suram A, Jaco I, Benitez J, Herbig U, et al. 2010 BRCA2 acts as a RAD51 loader to facilitate telomere replication and capping. Nature Structural \& Molecular Biology 17 1461-1469. (doi:10.1038/nsmb.1943)

Bahassi EM, Ovesen JL, Riesenberg AL, Bernstein WZ, Hasty PE \& Stambrook PJ 2008 The checkpoint kinases Chk1 and Chk2 regulate the functional associations between hBRCA2 and Rad51 in response to DNA damage. Oncogene 27 3977-3985. (doi:10.1038/onc.2008.17)

Benada J, Burdova K, Lidak T, von Morgen P \& Macurek L 2015 Polo-like kinase 1 inhibits DNA damage response during mitosis. Cell Cycle 14 219-231. (doi:10.4161/15384101.2014.977067)

Bennett CB, Lewis AL, Baldwin KK \& Resnick MA 1993 Lethality induced by a single site-specific double-strand break in a dispensable yeast plasmid. PNAS 90 5613-5617. (doi:10.1038/nrn1703)

Berti M \& Vindigni A 2016 Replication stress: getting back on track. Nature Structural \& Molecular Biology 23 103-109. (doi:10.1038/nsmb.3163)

Betermier M, Bertrand P \& Lopez BS 2014 Is non-homologous end-joining really an inherently error-prone process? PLoS Genetics 10 e1004086. (doi:10.1371/journal.pgen.1004086)

Bhatia V, Barroso SI, Garcia-Rubio ML, Tumini E, Herrera-Moyano E \& Aguilera A 2014 BRCA2 prevents R-loop accumulation and associates 
with TREX-2 mRNA export factor PCID2. Nature 511 362-365. (doi:10.1038/nature13374)

Bignell G, Micklem G, Stratton MR, Ashworth A \& Wooster R 1997 The BRC repeats are conserved in mammalian BRCA2 proteins. Human Molecular Genetics 6 53-58. (doi:10.1093/hmg/6.1.53)

Biswas K, Das R, Eggington JM, Qiao H, North SL, Stauffer S, Burkett SS, Martin BK, Southon E, Sizemore SC, et al. 2012 Functional evaluation of BRCA2 variants mapping to the PALB2binding and C-terminal DNA-binding domains using a mouse ES cell-based assay. Human Molecular Genetics 21 3993-4006. (doi:10.1093/hmg/dds222)

Blackburn EH \& Collins K 2011 Telomerase: an RNP enzyme synthesizes DNA. Cold Spring Harbor Perspectives in Biology 3 1-9. (doi:10.1101/ cshperspect.a003558)

Boersma V, Moatti N, Segura-Bayona S, Peuscher MH, van der Torre J, Wevers BA, Orthwein A, Durocher D \& Jacobs JJ 2015 MAD2L2 controls DNA repair at telomeres and DNA breaks by inhibiting 5 end resection. Nature 521 537-540. (doi:10.1038/nature14216)

Bork P, Blomberg N \& Nilges M 1996 Internal repeats in the BRCA2 protein sequence. Nature Genetics 13 22-23. (doi:10.1038/ng0596-22)

Brough R, Bajrami I, Vatcheva R, Natrajan R, Reis-Filho JS, Lord CJ \& Ashworth A 2012 APRIN is a cell cycle specific BRCA2-interacting protein required for genome integrity and a predictor of outcome after chemotherapy in breast cancer. EMBO Journal 31 1160-1176. (doi:10.1038/emboj.2011.490)

Bryant HE, Schultz N, Thomas HD, Parker KM, Flower D, Lopez E, Kyle S, Meuth M, Curtin NJ \& Helleday T 2005 Specific killing of BRCA2-deficient tumours with inhibitors of poly(ADP-ribose) polymerase. Nature 434 913-917. (doi:10.1038/nature03443)

Bryant HE, Petermann E, Schultz N, Jemth AS, Loseva O, Issaeva N, Johansson F, Fernandez S, McGlynn P \& Helleday T 2009 PARP is activated at stalled forks to mediate Mre11-dependent replication restart and recombination. EMBO Journal 28 2601-2615. (doi:10.1038/emboj.2009.206)

Buis J, Wu Y, Deng Y, Leddon J, Westfield G, Eckersdorff M, Sekiguchi JM, Chang S \& Ferguson DO 2008 Mre11 nuclease activity has essential roles in DNA repair and genomic stability distinct from ATM activation. Cell 135 85-96. (doi:10.1016/j.cell.2008.08.015)

Buisson R, Niraj J, Pauty J, Maity R, Zhao W, Coulombe Y, Sung P \& Masson JY 2014 Breast cancer proteins PALB2 and BRCA2 stimulate polymerase eta in recombination-associated DNA synthesis at blocked replication forks. Cell Reports 6 553-564. (doi:10.1016/j. celrep.2014.01.009)

Callen E, Di Virgilio M, Kruhlak MJ, Nieto-Soler M, Wong N, Chen HT, Faryabi RB, Polato F, Santos M, Starnes LM, et al. 2013 53BP1 mediates productive and mutagenic DNA repair through distinct phosphoprotein interactions. Cell 153 1266-1280. (doi:10.1016/j.cell.2013.05.023)

Carreira A \& Kowalczykowski SC 2011 Two classes of BRC repeats in BRCA2 promote RAD51 nucleoprotein filament function by distinct mechanisms. PNAS 108 10448-10453. (doi:10.1073/pnas.1106971108)

Ceccaldi R, Sarangi P \& D'Andrea AD 2016 The Fanconi anaemia pathway: new players and new functions. Nature Reviews Molecular Cell Biology 17 337-349. (doi:10.1038/nrm.2016.48)

Cejka P, Cannavo E, Polaczek P, Masuda-Sasa T, Pokharel S, Campbell JL \& Kowalczykowski SC 2010 DNA end resection by Dna2-Sgs1-RPA and its stimulation by Top3-Rmi1 and Mre11-Rad50-Xrs2. Nature 467 112-116. (doi:10.1038/nature09355)

Chapman JR, Sossick AJ, Boulton SJ \& Jackson SP 2012 BRCA1associated exclusion of 53BP1 from DNA damage sites underlies temporal control of DNA repair. Journal of Cell Science $\mathbf{1 2 5}$ 3529-3534. (doi:10.1242/jcs.105353)

Chapman JR, Barral P, Vannier JB, Borel V, Steger M, Tomas-Loba A, Sartori AA, Adams IR, Batista FD \& Boulton SJ 2013 RIF1 is essential for 53BP1-dependent nonhomologous end joining and suppression of DNA double-strand break resection. Molecular Cell 49 858-871. (doi:10.1016/j.molcel.2013.01.002)
Chaudhuri AR, Callen E, Ding X, Gogola E, Duarte AA, Lee JE, Wong N, Lafarga V, Calvo JA, Panzarino NJ, et al. 2016 Replication fork stability confers chemoresistance in BRCA-deficient cells. Nature $\mathbf{5 3 5}$ 382-387. (doi:10.1038/nature18325)

Chaudhury I, Stroik DR \& Sobeck A 2014 FANCD2-controlled chromatin access of the Fanconi-associated nuclease FAN1 is crucial for the recovery of stalled replication forks. Molecular and Cellular Biology 34 3939-3954. (doi:10.1128/MCB.00457-14)

Chen J, Silver DP, Walpita D, Cantor SB, Gazdar AF, Tomlinson G, Couch FJ, Weber BL, Ashley T, Livingston DM, et al. 1998a Stable interaction between the products of the BRCA1 and BRCA2 tumor suppressor genes in mitotic and meiotic cells. Molecular Cell 2 317-328. (doi:10.1016/S1097-2765(00)80276-2)

Chen PL, Chen CF, Chen Y, Xiao J, Sharp ZD \& Lee WH $1998 b$ The BRC repeats in BRCA2 are critical for RAD51 binding and resistance to methyl methanesulfonate treatment. PNAS 95 5287-5292. (doi:10.1073/pnas.95.9.5287)

Chen CF, Chen PL, Zhong Q, Sharp ZD \& Lee WH 1999 Expression of BRC repeats in breast cancer cells disrupts the BRCA2-Rad51 complex and leads to radiation hypersensitivity and loss of $\mathrm{G}(2) / \mathrm{M}$ checkpoint control. Journal of Biological Chemistry 274 32931-32935. (doi:10.1074/jbc.274.46.32931)

Choi E, Park PG, Lee HO, Lee YK, Kang GH, Lee JW, Han W, Lee HC, Noh DY, Lekomtsev S, et al. 2012 BRCA2 fine-tunes the spindle assembly checkpoint through reinforcement of BubR1 acetylation. Developmental Cell 22 295-308. (doi:10.1016/j.devcel. 2012.01.009)

Chourasia AH, Boland ML \& Macleod KF 2015 Mitophagy and cancer Cancer \& Metabolism 3 4. (doi:10.1186/s40170-015-0130-8)

Costanzo V, Robertson K, Bibikova M, Kim E, Grieco D, Gottesman M, Carroll D \& Gautier J 2001 Mre11 protein complex prevents doublestrand break accumulation during chromosomal DNA replication. Molecular Cell 8 137-147. (doi:10.1016/S1097-2765(01)00294-5)

Cousineau I \& Belmaaza A 2011 EMSY overexpression disrupts the BRCA2/RAD51 pathway in the DNA-damage response: implications for chromosomal instability/recombination syndromes as checkpoint diseases. Molecular Genetics and Genomics 285 325-340. (doi:10.1007/ s00438-011-0612-5)

Cruz-Garcia A, Lopez-Saavedra A \& Huertas P 2014 BRCA1 accelerates CtIP-mediated DNA-end resection. Cell Reports 9 451-459. (doi:10.1016/j.celrep.2014.08.076)

Daniels MJ, Wang Y, Lee M \& Venkitaraman AR 2004 Abnormal cytokinesis in cells deficient in the breast cancer susceptibility protein BRCA2. Science 306 876-879. (doi:10.1126/ science.1102574)

Dantuma NP \& van Attikum H 2016 Spatiotemporal regulation of posttranslational modifications in the DNA damage response. EMBO Journal 35 6-23. (doi:10.15252/embj.201592595)

Davies OR \& Pellegrini L 2007 Interaction with the BRCA2 C terminus protects RAD51-DNA filaments from disassembly by BRC repeats. Nature Structural \& Molecular Biology 14 475-483. (doi:10.1038/ nsmb1251)

Dhillon KK, Bajrami I, Taniguchi T \& Lord CJ 2016 Synthetic lethality: the road to novel therapies 1 for breast cancer. Endocrine-Related Cancer 23 T39-T55. (doi:10.1530/erc-16-0228)

Di Virgilio M, Callen E, Yamane A, Zhang W, Jankovic M, Gitlin AD, Feldhahn N, Resch W, Oliveira TY, Chait BT, et al. 2013 Rif1 prevents resection of DNA breaks and promotes immunoglobulin class switching. Science 339 711-715. (doi:10.1126/science.1230624)

Dobbelstein M \& Sorensen CS 2015 Exploiting replicative stress to treat cancer. Nature reviews. Drug Discovery 14 405-423. (doi:10.1038/ $\operatorname{nrd4553)}$

Doksani Y \& de Lange T 2014 The role of double-strand break repair pathways at functional and dysfunctional telomeres. Cold Spring Harbor Perspectives in Biology 6 a016576. (doi:10.1016/ j.neuroscience.2005.05.023) 
Donoho G, Brenneman MA, Cui TX, Donoviel D, Vogel H, Goodwin EH, Chen DJ \& Hasty P 2003 Deletion of Brca2 exon 27 causes hypersensitivity to DNA crosslinks, chromosomal instability, and reduced life span in mice. Genes Chromosomes and Cancer $\mathbf{3 6}$ 317-331. (doi:10.1002/gcc.10148)

Dray E, Siaud N, Dubois E \& Doutriaux MP 2006 Interaction between Arabidopsis Brca2 and its partners Rad51, Dmc1, and Dss1. Plant Physiology 140 1059-1069. (doi:10.1104/pp.105.075838)

Esashi F, Christ N, Gannon J, Liu Y, Hunt T, Jasin M \& West SC 2005 CDK-dependent phosphorylation of BRCA2 as a regulatory mechanism for recombinational repair. Nature 434 598-604. (doi:10.1038/nature03404)

Esashi F, Galkin VE, Yu X, Egelman EH \& West SC 2007 Stabilization of RAD51 nucleoprotein filaments by the C-terminal region of BRCA2 Nature Structural \& Molecular Biology 14 468-474. (doi:10.1038/ nsmb1245)

Escribano-Diaz C, Orthwein A, Fradet-Turcotte A, Xing M, Young JT, Tkac J, Cook MA, Rosebrock AP, Munro M, Canny MD, et al. 2013 A cell cycle-dependent regulatory circuit composed of 53BP1-RIF1 and BRCA1-CtIP controls DNA repair pathway choice. Molecular Cell 49 872-883. (doi:10.1016/j.molcel.2013.01.001)

Farmer H, McCabe N, Lord CJ, Tutt AN, Johnson DA, Richardson TB, Santarosa M, Dillon KJ, Hickson I, Knights C, et al. 2005 Targeting the DNA repair defect in BRCA mutant cells as a therapeutic strategy. Nature 434 917-921. (doi:10.1038/nature03445)

Feng L, Fong KW, Wang J, Wang W \& Chen J 2013 RIF1 counteracts BRCA1-mediated end resection during DNA repair. Journal of Biological Chemistry 288 11135-11143. (doi:10.1074/jbc. M113.457440)

Flynn RL \& Zou L 2010 Oligonucleotide/oligosaccharide-binding fold proteins: a growing family of genome guardians. Critical Reviews in Biochemistry and Molecular Biology 45 266-275. (doi:10.3109/1040923 8.2010.488216)

Flynn RL \& Zou L 2011 ATR: a master conductor of cellular responses to DNA replication stress. Trends in Biochemical Sciences 36 133-140. (doi:10.1016/j.tibs.2010.09.005)

Fradet-Turcotte A, Canny MD, Escribano-Diaz C, Orthwein A, Leung CC, Huang H, Landry MC, Kitevski-LeBlanc J, Noordermeer SM, Sicheri F, et al. 2013 53BP1 is a reader of the DNA-damage-induced H2A Lys 15 ubiquitin mark. Nature 499 50-54. (doi:10.1038/nature12318)

Fuks F, Milner J \& Kouzarides T 1998 BRCA2 associates with acetyltransferase activity when bound to P/CAF. Oncogene $\mathbf{1 7}$ 2531-2534. (doi:10.1038/sj.onc.1202475)

Galkin VE, Esashi F, Yu X, Yang S, West SC \& Egelman EH 2005 BRCA2 BRC motifs bind RAD51-DNA filaments. PNAS $1028537-8542$. (doi:10.1073/pnas.0407266102)

Garcia V, Phelps SE, Gray S \& Neale MJ 2011 Bidirectional resection of DNA double-strand breaks by Mre11 and Exo1. Nature 479 241-244. (doi:10.1038/nature10515)

Garcia-Rubio ML, Perez-Calero C, Barroso SI, Tumini E, HerreraMoyano E, Rosado IV \& Aguilera A 2015 The Fanconi anemia pathway protects genome integrity from R-loops. PLoS Genetics $\mathbf{1 1}$ e1005674. (doi:10.1371/journal.pgen.1005674)

Goldstein M \& Kastan MB 2015 The DNA damage response: implications for tumor responses to radiation and chemotherapy. Annual Review of Medicine 66 129-143. (doi:10.1146/annurevmed-081313-121208)

Gowen LC, Johnson BL, Latour AM, Sulik KK \& Koller BH 1996 Brca1 deficiency results in early embryonic lethality characterized by neuroepithelial abnormalities. Nature Genetics 12 191-194. (doi:10.1038/ng0296-191)

Gravel S, Chapman JR, Magill C \& Jackson SP 2008 DNA helicases Sgs1 and BLM promote DNA double-strand break resection. Genes \& Development 22 2767-2772. (doi:10.1101/gad.503108)

Gudmundsdottir K, Lord CJ, Witt E, Tutt AN \& Ashworth A 2004 DSS1 is required for RAD51 focus formation and genomic stability in mammalian cells. EMBO Reports 5 989-993. (doi:10.1038/sj.embor. 7400255)

Guidugli L, Carreira A, Caputo SM, Ehlen A, Galli A, Monteiro AN, Neuhausen SL, Hansen TV, Couch FJ, Vreeswijk MP, et al. 2014 Functional assays for analysis of variants of uncertain significance in BRCA2. Human Mutation 35 151-164. (doi:10.1002/humu.22478)

Guillemette S, Serra RW, Peng M, Hayes JA, Konstantinopoulos PA, Green MR \& Cantor SB 2015 Resistance to therapy in BRCA2 mutant cells due to loss of the nucleosome remodeling factor CHD4. Genes \& Development 29 489-494. (doi:10.1101/gad.256214.114)

Guirouilh-Barbat J, Lambert S, Bertrand P \& Lopez BS 2014 Is homologous recombination really an error-free process? Frontiers in Genetics 5 175. (doi:10.3389/fgene.2014.00175)

Hakansson S, Johannsson O, Johansson U, Sellberg G, Loman N, Gerdes AM, Holmberg E, Dahl N, Pandis N, Kristoffersson U, et al. 1997 Moderate frequency of BRCA1 and BRCA2 germ-line mutations in Scandinavian familial breast cancer. American Journal of Human Genetics 60 1068-1078.

Hakem R, de la Pompa JL, Sirard C, Mo R, Woo M, Hakem A, Wakeham A, Potter J, Reitmair A, Billia F, et al. 1996 The tumor suppressor gene Brca1 is required for embryonic cellular proliferation in the mouse. Cell 85 1009-1023. (doi:10.1016/S00928674(00)81302-1)

Han X, Saito H, Miki Y \& Nakanishi A 2008 A CRM1-mediated nuclear export signal governs cytoplasmic localization of BRCA2 and is essential for centrosomal localization of BRCA2. Oncogene $\mathbf{2 7}$ 2969-2977. (doi:10.1038/sj.onc.1210968)

Hashimoto Y, Ray Chaudhuri A, Lopes M \& Costanzo V 2010 Rad51 protects nascent DNA from Mre11-dependent degradation and promotes continuous DNA synthesis. Nature Structural \& Molecular Biology 17 1305-1311. (doi:10.1038/nsmb.1927)

Hatchi E, Skourti-Stathaki K, Ventz S, Pinello L, Yen A, Kamieniarz-Gdula K, Dimitrov S, Pathania S, McKinney KM, Eaton ML, et al. 2015 BRCA1 recruitment to transcriptional pause sites is required for R-loop-driven DNA damage repair. Molecular Cell 57 636-647. (doi:10.1016/j.molcel.2015.01.011)

Helleday T, Eshtad S \& Nik-Zainal S 2014 Mechanisms underlying mutational signatures in human cancers. Nature Reviews Genetics $\mathbf{1 5}$ 585-598. (doi: $10.1038 / \operatorname{nrg} 3729$ )

Higgs MR, Reynolds JJ, Winczura A, Blackford AN, Borel V, Miller ES, Zlatanou A, Nieminuszczy J, Ryan EL, Davies NJ, et al. 2015 BOD1L is required to suppress deleterious resection of stressed replication forks. Molecular Cell 59 462-477. (doi:10.1016/j.molcel.2015. 06.007)

Hohenstein P, Kielman MF, Breukel C, Bennett LM, Wiseman R, Krimpenfort P, Cornelisse C, van Ommen GJ, Devilee P \& Fodde R 2001 A targeted mouse Brca1 mutation removing the last BRCT repeat results in apoptosis and embryonic lethality at the headfold stage. Oncogene 20 2544-2550. (doi:10.1038/sj.onc.1204363)

Howlett NG, Taniguchi T, Olson S, Cox B, Waisfisz Q, De Die-Smulders C, Persky N, Grompe M, Joenje H, Pals G, et al. 2002 Biallelic inactivation of BRCA2 in Fanconi anemia. Science 297 606-609. (doi:10.1126/science.1073834)

Huertas P, Cortes-Ledesma F, Sartori AA, Aguilera A \& Jackson SP 2008 CDK targets Sae2 to control DNA-end resection and homologous recombination. Nature 455 689-692. (doi:10.1038/nature07215)

Hughes-Davies L, Huntsman D, Ruas M, Fuks F, Bye J, Chin SF, Milner J, Brown LA, Hsu F, Gilks B, et al. 2003 EMSY links the BRCA2 pathway to sporadic breast and ovarian cancer. Cell 115 523-535. (doi:10.1016/S0092-8674(03)00930-9)

Hussain S, Wilson JB, Medhurst AL, Hejna J, Witt E, Ananth S, Davies A, Masson JY, Moses R, West SC, et al. 2004 Direct interaction of FANCD2 with BRCA2 in DNA damage response pathways. Human Molecular Genetics 13 1241-1248. (doi:10.1093/hmg/ddh135)

Huyen Y, Zgheib O, Ditullio RA Jr, Gorgoulis VG, Zacharatos P, Petty TJ, Sheston EA, Mellert HS, Stavridi ES \& Halazonetis TD 2004 
Methylated lysine 79 of histone $\mathrm{H} 3$ targets 53BP1 to DNA doublestrand breaks. Nature 432 406-411. (doi:10.1038/nature03114)

Jeyasekharan AD, Liu Y, Hattori H, Pisupati V, Jonsdottir AB, Rajendra E, Lee M, Sundaramoorthy E, Schlachter S, Kaminski CF, et al. 2013 A cancer-associated BRCA2 mutation reveals masked nuclear export signals controlling localization. Nature Structural \& Molecular Biology 20 1191-1198. (doi:10.1038/nsmb.2666)

Jiang Q, Paramasivam M, Aressy B, Wu J, Bellani M, Tong W, Seidman MM \& Greenberg RA 2015 MERIT40 cooperates with BRCA2 to resolve DNA interstrand cross-links. Genes \& Development 29 1955-1968. (doi:10.1101/gad.264192.115)

Kais Z, Rondinelli B, Holmes A, O'Leary C, Kozono D, D'Andrea AD \& Ceccaldi R 2016 FANCD2 maintains fork stability in BRCA1/2-deficient tumors and promotes alternative end-joining DNA repair. Cell Reports 15 2488-2499. (doi:10.1016/j.celrep. 2016.05.031)

Karanja KK, Lee EH, Hendrickson EA \& Campbell JL 2014 Preventing over-resection by DNA2 helicase/nuclease suppresses repair defects in Fanconi anemia cells. Cell Cycle 13 1540-1550. (doi:10.4161/ cc.28476)

Kee Y \& D'Andrea AD 2012 Molecular pathogenesis and clinical management of Fanconi anemia. Journal of Clinical Investigation 122 3799-3806. (doi:10.1172/JCI58321)

Krawczyk PM, Borovski T, Stap J, Cijsouw T, ten Cate R, Medema JP, Kanaar R, Franken NA \& Aten JA 2012 Chromatin mobility is increased at sites of DNA double-strand breaks. Journal of Cell Science 125 2127-2133. (doi:10.1242/jcs.089847)

Kruhlak MJ, Celeste A, Dellaire G, Fernandez-Capetillo O, Muller WG, McNally JG, Bazett-Jones DP \& Nussenzweig A 2006 Changes in chromatin structure and mobility in living cells at sites of DNA double-strand breaks. Journal of Cell Biology 172 823-834. (doi:10.1083/jcb.200510015)

Kusch T 2015 Brca2-Pds5 complexes mobilize persistent meiotic recombination sites to the nuclear envelope. Journal of Cell Science 128 717-727. (doi:10.1242/jcs.159988)

Lachaud C, Moreno A, Marchesi F, Toth R, Blow JJ \& Rouse J 2016 Ubiquitinated Fancd2 recruits Fan1 to stalled replication forks to prevent genome instability. Science 351 846-849. (doi:10.1126/ science.aad5634)

Lamarche BJ, Orazio NI \& Weitzman MD 2010 The MRN complex in double-strand break repair and telomere maintenance. FEBS Letters 584 3682-3695. (doi:10.1016/j.febslet.2010.07.029)

Lee H 2014 Cycling with BRCA2 from DNA repair to mitosis. Experimental Cell Research 329 78-84. (doi:10.1016/j.yexcr.2014. 10.008)

Lee DH, Acharya SS, Kwon M, Drane P, Guan Y, Adelmant G, Kalev P, Shah J, Pellman D, Marto JA, et al. 2014 Dephosphorylation enables the recruitment of 53BP1 to double-strand DNA breaks. Molecular Cell 54 512-525. (doi:10.1016/j.molcel.2014.03.020)

Li SS, Tseng HM, Yang TP, Liu CH, Teng SJ, Huang HW, Chen LM, Kao HW, Chen JH, Tseng JN, et al. 1999 Molecular characterization of germline mutations in the BRCA1 and BRCA2 genes from breast cancer families in Taiwan. Human Genetics 104 201-204. (doi:10.1007/s004390050936)

Li J, Zou C, Bai Y, Wazer DE, Band V \& Gao Q 2006 DSS1 is required for the stability of BRCA2. Oncogene 25 1186-1194. (doi:10.1038/sj.onc. 1209153)

Lim DS \& Hasty P 1996 A mutation in mouse rad51 results in an early embryonic lethal that is suppressed by a mutation in p53. Molecular and Cellular Biology 16 7133-7143. (doi:10.1128/MCB.16.12.7133)

Liu CY, Flesken-Nikitin A, Li S, Zeng Y \& Lee WH 1996 Inactivation of the mouse Brca1 gene leads to failure in the morphogenesis of the egg cylinder in early postimplantation development. Genes \& Development 10 1835-1843. (doi:10.1101/gad.10.14.1835)

Lomonosov M, Anand S, Sangrithi M, Davies R \& Venkitaraman AR 2003 Stabilization of stalled DNA replication forks by the BRCA2 breast cancer susceptibility protein. Genes \& Development $\mathbf{1 7}$ 3017-3022. (doi:10.1101/gad.279003)

Long DT, Raschle M, Joukov V \& Walter JC 2011 Mechanism of RAD51dependent DNA interstrand cross-link repair. Science 333 84-87. (doi:10.1126/science.1204258)

Lord CJ \& Ashworth A 2013 Mechanisms of resistance to therapies targeting BRCA-mutant cancers. Nature Medicine 19 1381-1388. (doi:10.1038/nm.3369)

Lossaint G, Larroque M, Ribeyre C, Bec N, Larroque C, Decaillet C, Gari K \& Constantinou A 2013 FANCD2 binds MCM proteins and controls replisome function upon activation of s phase checkpoint signaling. Molecular Cell 51 678-690. (doi:10.1016/j. molcel.2013.07.023)

Lottersberger F, Karssemeijer RA, Dimitrova N \& de Lange T 2015 53BP1 and the LINC complex promote microtubule-dependent DSB mobility and DNA repair. Cell 163 880-893. (doi:10.1016/j. cell.2015.09.057)

Ludwig T, Chapman DL, Papaioannou VE \& Efstratiadis A 1997 Targeted mutations of breast cancer susceptibility gene homologs in mice: lethal phenotypes of Brca1, Brca2, Brca1/Brca2, Brca1/p53, and Brca2/p53 nullizygous embryos. Genes \& Development 11 1226-1241. (doi:10.1101/gad.11.10.1226)

Marston NJ, Richards WJ, Hughes D, Bertwistle D, Marshall CJ \& Ashworth A 1999 Interaction between the product of the breast cancer susceptibility gene BRCA2 and DSS1, a protein functionally conserved from yeast to mammals. Molecular and Cellular Biology 19 4633-4642. (doi:10.1128/MCB.19.7.4633)

Martinez JS, von Nicolai C, Kim T, Ehlen A, Mazin AV, Kowalczykowski SC \& Carreira A 2016 BRCA2 regulates DMC1mediated recombination through the BRC repeats. PNAS $\mathbf{1 1 3}$ 3515-3520. (doi:10.1073/pnas.1601691113)

Matsuoka S, Ballif BA, Smogorzewska A, McDonald ER 3rd, Hurov KE, Luo J, Bakalarski CE, Zhao Z, Solimini N, Lerenthal Y, et al. 2007 ATM and ATR substrate analysis reveals extensive protein networks responsive to DNA damage. Science 316 1160-1166. (doi:10.1126/ science.1140321)

McAllister KA, Bennett LM, Houle CD, Ward T, Malphurs J, Collins NK, Cachafeiro C, Haseman J, Goulding EH, Bunch D, et al. 2002 Cancer susceptibility of mice with a homozygous deletion in the $\mathrm{COOH}$-terminal domain of the Brca2 gene. Cancer Research 62 990-994.

Michl J, Zimmer J, Buffa FM, McDermott U \& Tarsounas M 2016 FANCD2 limits replication stress and genome instability in cells lacking BRCA2. Nature Structural \& Molecular Biology 23 755-757. (doi:10.1038/nsmb.3252)

Mimitou EP \& Symington LS 2008 Sae2, Exo1 and Sgs1 collaborate in DNA double-strand break processing. Nature 455 770-774. (doi:10.1038/nature07312)

Min J, Choi ES, Hwang K, Kim J, Sampath S, Venkitaraman AR \& Lee H 2012 The breast cancer susceptibility gene BRCA2 is required for the maintenance of telomere homeostasis. Journal of Biological Chemistry 287 5091-5101. (doi:10.1074/jbc.M111.278994)

Mizuta R, LaSalle JM, Cheng HL, Shinohara A, Ogawa H, Copeland N, Jenkins NA, Lalande M \& Alt FW 1997 RAB22 and RAB163/mouse BRCA2: proteins that specifically interact with the RAD51 protein. PNAS 94 6927-6932. (doi:10.1073/pnas.94.13.6927)

Mondal G, Rowley M, Guidugli L, Wu J, Pankratz VS \& Couch FJ 2012 BRCA2 localization to the midbody by filamin A regulates cep55 signaling and completion of cytokinesis. Developmental Cell 23 137-152. (doi:10.1016/j.devcel.2012.05.008)

Morimatsu M, Donoho G \& Hasty P 1998 Cells deleted for Brca2 COOH terminus exhibit hypersensitivity to gamma-radiation and premature senescence. Cancer Research 58 3441-3447.

Moynahan ME, Pierce AJ \& Jasin M 2001 BRCA2 is required for homology-directed repair of chromosomal breaks. Molecular Cell 7 263-272. (doi:10.1016/S1097-2765(01)00174-5) 
Nakamura K, Kogame T, Oshiumi H, Shinohara A, Sumitomo Y, Agama K, Pommier Y, Tsutsui KM, Tsutsui K, Hartsuiker E, et al. 2010 Collaborative action of Brca1 and CtIP in elimination of covalent modifications from double-strand breaks to facilitate subsequent break repair. PLoS Genetics 6 e1000828. (doi:10.1371/journal. pgen.1000828)

Nakanishi A, Han X, Saito H, Taguchi K, Ohta Y, Imajoh-Ohmi S \& Miki Y 2007 Interference with BRCA2, which localizes to the centrosome during $\mathrm{S}$ and early $\mathrm{M}$ phase, leads to abnormal nuclear division. Biochemical and Biophysical Research Communications $\mathbf{3 5 5}$ 34-40. (doi:10.1016/j.bbrc.2007.01.100)

Nimonkar AV, Ozsoy AZ, Genschel J, Modrich P \& Kowalczykowski SC 2008 Human exonuclease 1 and BLM helicase interact to resect DNA and initiate DNA repair. PNAS 105 16906-16911. (doi:10.1073/ pnas.0809380105)

Nimonkar AV, Genschel J, Kinoshita E, Polaczek P, Campbell JL, Wyman C, Modrich P \& Kowalczykowski SC 2011 BLM-DNA2-RPAMRN and EXO1-BLM-RPA-MRN constitute two DNA end resection machineries for human DNA break repair. Genes \& Development 25 350-362. (doi:10.1101/gad.2003811)

Niu H, Chung WH, Zhu Z, Kwon Y, Zhao W, Chi P, Prakash R, Seong C, Liu D, Lu L, et al. 2010 Mechanism of the ATP-dependent DNA end-resection machinery from Saccharomyces cerevisiae. Nature 467 108-111. (doi:10.1038/nature09318)

Oliver AW, Swift S, Lord CJ, Ashworth A \& Pearl LH 2009 Structural basis for recruitment of BRCA2 by PALB2. EMBO Reports 10 990-996. (doi:10.1038/embor.2009.126)

Orthwein A, Fradet-Turcotte A, Noordermeer SM, Canny MD, Brun CM, Strecker J, Escribano-Diaz C \& Durocher D 2014 Mitosis inhibits DNA double-strand break repair to guard against telomere fusions. Science 344 189-193. (doi:10.1126/science.1248024)

Orthwein A, Noordermeer SM, Wilson MD, Landry S, Enchev RI, Sherker A, Munro M, Pinder J, Salsman J, Dellaire G, et al. 2015 A mechanism for the suppression of homologous recombination in G1 cells. Nature 528 422-426. (doi:10.1038/nature16142)

Patel KJ, Yu VP, Lee H, Corcoran A, Thistlethwaite FC, Evans MJ, Colledge WH, Friedman LS, Ponder BA \& Venkitaraman AR 1998 Involvement of Brca2 in DNA repair. Molecular Cell 1 347-357. (doi:10.1016/S1097-2765(00)80035-0)

Pauty J, Rodrigue A, Couturier A, Buisson R \& Masson JY 2014 Exploring the roles of PALB2 at the crossroads of DNA repair and cancer. Biochemical Journal 460 331-342. (doi:10.1042/BJ20140208)

Pefani DE, Latusek R, Pires I, Grawenda AM, Yee KS, Hamilton G, van der Weyden L, Esashi F, Hammond EM \& O'Neill E 2015 RASSF1A-LATS1 signalling stabilizes replication forks by restricting CDK2-mediated phosphorylation of BRCA2. Nature Cell Biology 17 531. (doi:10.1038/ncb3152)

Pellegrini L, Yu DS, Lo T, Anand S, Lee M, Blundell TL \& Venkitaraman AR 2002 Insights into DNA recombination from the structure of a RAD51-BRCA2 complex. Nature 420 287-293. (doi:10.1038/nature01230)

Petermann E, Orta ML, Issaeva N, Schultz N \& Helleday T 2010 Hydroxyurea-stalled replication forks become progressively inactivated and require two different RAD51-mediated pathways for restart and repair. Molecular Cell 37 492-502. (doi:10.1016/j. molcel.2010.01.021)

Polato F, Callen E, Wong N, Faryabi R, Bunting S, Chen HT, Kozak M, Kruhlak MJ, Reczek CR, Lee WH, et al. 2014 CtIP-mediated resection is essential for viability and can operate independently of BRCA1. Journal of Experimental Medicine 211 1027-1036. (doi:10.1084/ jem.20131939)

Raghunandan M, Chaudhury I, Kelich SL, Hanenberg H \& Sobeck A 2015 FANCD2, FANCJ and BRCA2 cooperate to promote replication fork recovery independently of the Fanconi Anemia core complex. Cell Cycle 14 342-353. (doi:10.4161/15384101. 2014.987614)
Rajendra E \& Venkitaraman AR 2010 Two modules in the BRC repeats of BRCA2 mediate structural and functional interactions with the RAD51 recombinase. Nucleic Acids Research 38 82-96. (doi:10.1093/ nar/gkp873)

Reczek CR, Szabolcs M, Stark JM, Ludwig T \& Baer R 2013 The interaction between CtIP and BRCA1 is not essential for resectionmediated DNA repair or tumor suppression. Journal of Cell Biology 201 693-707. (doi:10.1083/jcb.201302145)

Roukos V, Voss TC, Schmidt CK, Lee S, Wangsa D \& Misteli T 2013 Spatial dynamics of chromosome translocations in living cells. Science 341 660-664. (doi:10.1126/science.1237150)

Saeki H, Siaud N, Christ N, Wiegant WW, van Buul PP, Han M, Zdzienicka MZ, Stark JM \& Jasin M 2006 Suppression of the DNA repair defects of BRCA2-deficient cells with heterologous protein fusions. PNAS 103 8768-8773. (doi:10.1073/pnas.0600298103)

Sandell LL \& Zakian VA 1993 Loss of a yeast telomere: arrest, recovery, and chromosome loss. Cell 75 729-739. (doi:10.1016/00928674(93)90493-A)

Schlacher K, Christ N, Siaud N, Egashira A, Wu H \& Jasin M 2011 Double-strand break repair-independent role for BRCA2 in blocking stalled replication fork degradation by MRE11. Cell 145 529-542. (doi:10.1016/j.cell.2011.03.041)

Schlacher K, Wu H \& Jasin M 2012 A distinct replication fork protection pathway connects Fanconi anemia tumor suppressors to RAD51BRCA1/2. Cancer Cell 22 106-116. (doi:10.1016/j.ccr.2012.05.015)

Schwab RA, Nieminuszczy J, Shah F, Langton J, Lopez Martinez D, Liang CC, Cohn MA, Gibbons RJ, Deans AJ \& Niedzwiedz W 2015 The Fanconi anemia pathway maintains genome stability by coordinating replication and transcription. Molecular Cell $\mathbf{6 0}$ 351-361. (doi:10.1016/j.molcel.2015.09.012)

Seeliger K, Dukowic-Schulze S, Wurz-Wildersinn R, Pacher M \& Puchta H 2012 BRCA2 is a mediator of RAD51- and DMC1facilitated homologous recombination in Arabidopsis thaliana. New Phytologist 193 364-375. (doi:10.1111/j.1469-8137. 2011.03947.x)

Shahid T, Soroka J, Kong EH, Malivert L, McIlwraith MJ, Pape T, West SC \& Zhang X 2014 Structure and mechanism of action of the BRCA2 breast cancer tumor suppressor. Nature Structural \& Molecular Biology 21 962-968. (doi:10.1038/nsmb.2899)

Sharan SK, Morimatsu M, Albrecht U, Lim DS, Regel E, Dinh C, Sands A, Eichele G, Hasty P \& Bradley A 1997 Embryonic lethality and radiation hypersensitivity mediated by Rad51 in mice lacking Brca2. Nature 386 804-810. (doi:10.1038/386804a0)

Sharan SK, Pyle A, Coppola V, Babus J, Swaminathan S, Benedict J, Swing D, Martin BK, Tessarollo L, Evans JP, et al. 2004 BRCA2 deficiency in mice leads to meiotic impairment and infertility. Development 131 131-142. (doi:10.1242/dev.00888)

Shen SX, Weaver Z, Xu X, Li C, Weinstein M, Chen L, Guan XY, Ried T \& Deng CX 1998 A targeted disruption of the murine Brca1 gene causes gamma-irradiation hypersensitivity and genetic instability. Oncogene 17 3115-3124. (doi:10.1038/sj.onc.1202243)

Shim EY, Chung WH, Nicolette ML, Zhang Y, Davis M, Zhu Z, Paull TT, Ira G \& Lee SE 2010 Saccharomyces cerevisiae Mre11/ Rad50/Xrs2 and $\mathrm{Ku}$ proteins regulate association of Exo1 and Dna2 with DNA breaks. EMBO Journal 29 3370-3380. (doi:10.1038/emboj.2010.219)

Shin S \& Verma IM 2003 BRCA2 cooperates with histone acetyltransferases in androgen receptor-mediated transcription. PNAS 100 7201-7206. (doi:10.1073/pnas.1132020100)

Siaud N, Dray E, Gy I, Gerard E, Takvorian N \& Doutriaux MP 2004 Brca2 is involved in meiosis in Arabidopsis thaliana as suggested by its interaction with Dmc1. EMBO Journal 23 1392-1401. (doi:10.1038/sj.emboj.7600146)

Siaud N, Barbera MA, Egashira A, Lam I, Christ N, Schlacher K, Xia B \& Jasin M 2011 Plasticity of BRCA2 function in homologous recombination: genetic interactions of the PALB2 and DNA binding 
domains. PLoS Genetics 7 e1002409. (doi:10.1371/journal. pgen.1002409)

Siddique H, Zou JP, Rao VN \& Reddy ES 1998 The BRCA2 is a histone acetyltransferase. Oncogene 16 2283-2285. (doi:10.1038/sj.onc. 1202003)

Sollier J \& Cimprich KA 2015 Breaking bad: R-loops and genome integrity. Trends in Cell Biology 25 514-522. (doi:10.1016/j.tcb. 2015.05.003)

Soutoglou E, Dorn JF, Sengupta K, Jasin M, Nussenzweig A, Ried T, Danuser G \& Misteli T 2007 Positional stability of single doublestrand breaks in mammalian cells. Nature Cell Biology 9 675-682. (doi:10.1038/ncb1591)

Sumpter R Jr, Sirasanagandla S, Fernandez AF, Wei Y, Dong X, Franco L, Zou Z, Marchal C, Lee MY, Clapp DW, et al. 2016 Fanconi anemia proteins function in mitophagy and immunity. Cell 165 867-881. (doi:10.1016/j.cell.2016.04.006)

Suzuki A, de la Pompa JL, Hakem R, Elia A, Yoshida R, Mo R, Nishina H, Chuang T, Wakeham A, Itie A, et al. 1997 Brca2 is required for embryonic cellular proliferation in the mouse. Genes \& Development 11 1242-1252. (doi:10.1101/gad.11.10.1242)

Sy SM, Huen MS \& Chen J 2009 PALB2 is an integral component of the BRCA complex required for homologous recombination repair. PNAS 106 7155-7160. (doi:10.1073/pnas.0811159106)

Tang J, Cho NW, Cui G, Manion EM, Shanbhag NM, Botuyan MV, Mer G \& Greenberg RA 2013 Acetylation limits 53BP1 association with damaged chromatin to promote homologous recombination. Nature Structural \& Molecular Biology 20 317-325. (doi:10.1038/ nsmb.2499)

Thangavel S, Berti M, Levikova M, Pinto C, Gomathinayagam S, Vujanovic M, Zellweger R, Moore H, Lee EH, Hendrickson EA, et al. 2015 DNA2 drives processing and restart of reversed replication forks in human cells. Journal of Cell Biology 208 545-562. (doi:10.1083/ jcb.201406100)

Thorslund T, Esashi F \& West SC 2007 Interactions between human BRCA2 protein and the meiosis-specific recombinase DMC1. EMBO Journal 26 2915-2922. (doi:10.1038/sj.emboj.7601739)

Trenz K, Smith E, Smith S \& Costanzo V 2006 ATM and ATR promote Mre11 dependent restart of collapsed replication forks and prevent accumulation of DNA breaks. EMBO Journal 25 1764-1774. (doi:10.1038/sj.emboj.7601045)

Tsuzuki T, Fujii Y, Sakumi K, Tominaga Y, Nakao K, Sekiguchi M, Matsushiro A, Yoshimura Y \& Morita T 1996 Targeted disruption of the Rad51 gene leads to lethality in embryonic mice. PNAS 93 6236-6240. (doi:10.1073/pnas.93.13.6236)

Tutt A, Gabriel A, Bertwistle D, Connor F, Paterson H, Peacock J, Ross G \& Ashworth A 1999 Absence of Brca2 causes genome instability by chromosome breakage and loss associated with centrosome amplification. Current Biology 9 1107-1110. (doi:10.1016/S09609822(99)80479-5)

Tutt A, Bertwistle D, Valentine J, Gabriel A, Swift S, Ross G, Griffin C, Thacker J \& Ashworth A 2001 Mutation in Brca2 stimulates errorprone homology-directed repair of DNA double-strand breaks occurring between repeated sequences. EMBO Journal 20 4704-4716. (doi:10.1093/emboj/20.17.4704)

Wang X, Andreassen PR \& D'Andrea AD 2004 Functional interaction of monoubiquitinated FANCD2 and BRCA2/FANCD1 in chromatin. Molecular and Cellular Biology 24 5850-5862. (doi:10.1128/ MCB.24.13.5850-5862.2004)

Wang HF, Takenaka K, Nakanishi A \& Miki Y 2011 BRCA2 and nucleophosmin coregulate centrosome amplification and form a complex with the Rho effector kinase ROCK2. Cancer Research $\mathbf{7 1}$ 68-77. (doi:10.1158/0008-5472.CAN-10-0030)

Wang J, Aroumougame A, Lobrich M, Li Y, Chen D, Chen J \& Gong Z 2014 PTIP associates with Artemis to dictate DNA repair pathway choice. Genes \& Development 28 2693-2698. (doi:10.1101/ gad.252478.114)
Wang AT, Kim T, Wagner JE, Conti BA, Lach FP, Huang AL, Molina H, Sanborn EM, Zierhut H, Cornes BK, et al. 2015 A dominant mutation in human RAD51 reveals its function in DNA interstrand crosslink repair independent of homologous recombination. Molecular Cell 59 478-490. (doi:10.1016/j.molcel.2015.07.009)

Wong AK, Pero R, Ormonde PA, Tavtigian SV \& Bartel PL 1997 RAD51 interacts with the evolutionarily conserved BRC motifs in the human breast cancer susceptibility gene brca2. Journal of Biological Chemistry 272 31941-31944. (doi:10.1074/jbc.272.51.31941)

Wooster R, Bignell G, Lancaster J, Swift S, Seal S, Mangion J, Collins N, Gregory S, Gumbs C \& Micklem G 1995 Identification of the breast cancer susceptibility gene BRCA2. Nature 378 789-792. (doi:10.1038/378789a0)

Xia B, Sheng Q, Nakanishi K, Ohashi A, Wu J, Christ N, Liu X, Jasin M, Couch FJ \& Livingston DM 2006 Control of BRCA2 cellular and clinical functions by a nuclear partner, PALB2. Molecular Cell 22 719-729. (doi:10.1016/j.molcel.2006.05.022)

Xu G, Chapman JR, Brandsma I, Yuan J, Mistrik M, Bouwman P, Bartkova J, Gogola E, Warmerdam D, Barazas M, et al. 2015 REV7 counteracts DNA double-strand break resection and affects PARP inhibition. Nature 521 541-544. (doi:10.1038/ nature 14328)

Yang H, Jeffrey PD, Miller J, Kinnucan E, Sun Y, Thoma NH, Zheng N Chen PL, Lee WH \& Pavletich NP 2002 BRCA2 function in DNA binding and recombination from a BRCA2-DSS1-ssDNA structure. Science 297 1837-1848. (doi:10.1126/science.297.5588.1837)

Yano K, Morotomi K, Saito H, Kato M, Matsuo F \& Miki Y 2000 Nuclear localization signals of the BRCA2 protein. Biochemical and Biophysical Research Communications 270 171-175. (doi:10.1006/ bbrc.2000.2392)

Yata K, Bleuyard JY, Nakato R, Ralf C, Katou Y, Schwab RA, Niedzwiedz W, Shirahige K \& Esashi F 2014 BRCA2 coordinates the activities of cell-cycle kinases to promote genome stability. Cell Reports 7 1547-1559. (doi:10.1016/j.celrep.2014.04.023)

Ying S, Hamdy FC \& Helleday T 2012 Mre11-dependent degradation of stalled DNA replication forks is prevented by BRCA2 and PARP1. Cancer Research 72 2814-2821. (doi:10.1158/0008-5472.CAN-113417)

Yuan SS, Lee SY, Chen G, Song M, Tomlinson GE \& Lee EY 1999 BRCA2 is required for ionizing radiation-induced assembly of Rad51 complex in vivo. Cancer Research 59 3547-3551.

Zellweger R, Dalcher D, Mutreja K, Berti M, Schmid JA, Herrador R, Vindigni A \& Lopes M 2015 Rad51-mediated replication fork reversal is a global response to genotoxic treatments in human cells. Journal of Cell Biology 208 563-579. (doi:10.1083/jcb. 201406099)

Zeman MK \& Cimprich KA 2014 Causes and consequences of replication stress. Nature Cell Biology 16 2-9. (doi:10.1038/ncb2897)

Zhang J \& Walter JC 2014 Mechanism and regulation of incisions during DNA interstrand cross-link repair. DNA Repair 19 135-142. (doi:10.1016/j.dnarep.2014.03.018)

Zhang F, Fan Q, Ren K \& Andreassen PR 2009a PALB2 functionally connects the breast cancer susceptibility proteins BRCA1 and BRCA2. Molecular Cancer Research 7 1110-1118. (doi:10.1158/1541-7786. MCR-09-0123)

Zhang F, Ma J, Wu J, Ye L, Cai H, Xia B \& Yu X 2009b PALB2 links BRCA1 and BRCA2 in the DNA-damage response. Current Biology 19 524-529. (doi:10.1016/j.cub.2009.02.018)

Zhang F, Shi J, Bian C \& Yu X 2015 Poly(ADP-Ribose) mediates the BRCA2-dependent early DNA damage response. Cell Reports $\mathbf{1 3}$ 678-689. (doi:10.1016/j.celrep.2015.09.040)

Zhao W, Vaithiyalingam S, San Filippo J, Maranon DG, Jimenez-Sainz J, Fontenay GV, Kwon Y, Leung SG, Lu L, Jensen RB, et al. 2015 Promotion of BRCA2-dependent homologous recombination by DSS1 via RPA targeting and DNA mimicry. Molecular Cell 59 176-187. (doi:10.1016/j.molcel.2015.05.032) 
Zhu Z, Chung WH, Shim EY, Lee SE \& Ira G 2008 Sgs1 helicase and two nucleases Dna2 and Exo1 resect DNA double-strand break ends. Cell 134 981-994. (doi:10.1016/j.cell.2008.08.037)

Zimmer J, Tacconi EM, Folio C, Badie S, Porru M, Klare K, Tumiati M, Markkanen E, Halder S, Ryan A, et al. 2016 Targeting BRCA1 and BRCA2 deficiencies with G-quadruplex-interacting compounds. Molecular Cell 61 449-460. (doi:10.1016/j.molcel.2015.12.004)
Zimmermann M \& de Lange T 2014 53BP1: pro choice in DNA repair. Trends in Cell Biology 24 108-117. (doi:10.1016/j.tcb. 2013.09.003)

Zimmermann M, Lottersberger F, Buonomo SB, Sfeir A \& de Lange T 2013 53BP1 regulates DSB repair using Rif1 to control 5' end resection. Science 339 700-704. (doi:10.1126/ science.1231573)

Received in final form 13 August 2016

Accepted 16 August 2016

Accepted Preprint published online 16 August 2016 